J. med. Genet. (1967). 4, 44 .

\title{
Human Polymorphism
}

\author{
J. PRICE* \\ From the Nuffield Unit of Medical Genetics, Department of Medicine, University of Liverpool $^{2}$
}

Ford (1940) has defined polymorphism as the occurrence together in the same habitat of two or more discontinuous forms or phases of a species in such proportions that the rarest of them cannot be maintained merely by recurrent mutation.

In his Genetic Polymorphism (1965) he states (p. 14) that 'A unifactorial character must be polymorphic if found even in $1 \%$ of a considerable population, amounting perhaps to 500 individuals or more, when random genetic drift may reasonably be excluded as unimportant'. This figure of $1 \%$ has been used in this paper as a rough dividing line between what needs to be mentioned and what does not.

Ford's definition excludes continuous variation, as exemplified by human height and skin colour, and it excludes rare disadvantageous recessive conditions, such as albinism and haemophilia.

Two types of polymorphism are included in the definition: the balanced and the transient. A polymorphism may be balanced, that is, with the ratio between two (or more) different characters remaining constant throughout many generations, through the operation of one of several mechanisms of which heterozygous advantage is the best known (see the section on blood groups). Alternatively, polymorphisms may be transient; if two discontinuous forms $(A)$ and $(B)$ exist, then in time one or other of the transitions $(\mathrm{A}) \rightarrow(\mathrm{A}+\mathrm{B}) \rightarrow(\mathrm{A})$ or $(\mathrm{A}) \rightarrow(\mathrm{A}+\mathrm{B})$ $\rightarrow(B)$ will take place. If a certain form has a $10 \%$ incidence in a population can we be sure whether it is increasing, decreasing, or stable in that population? The answer in many cases seems to be no, because of lack of knowledge of frequencies in the past and of the selective forces involved.

Genes always have multiple effects. It therefore follows that we may discover a polymorphism relating to one effect, for example red cell acid phosphatase, in which it is another property of the genes responsible for acid phosphatase production which is bringing about the polymorphic situation.

*Bates Research Fellow, Mental Health Research Fund.
If this were the case, any attempt to relate this $\frac{\text { s }}{3}$ polymorphism to differences in function of the various forms of acid phosphatase would plainly not + succeed.

So few selective mechanisms (similar to that relating sickle cell trait to falciparum malaria) 오 have been discovered, that the present position is that most polymorphisms described are, so to speak, 'in search of a disease', which they seem on present evidence unlikely to find. The selective factors may, of course, not be concerned with disease, but be connected with fertility, ability to gather food, and other forms of fitness.

This fruitless searching for selective mechanisms which will give a clear-cut explanation of known polymorphisms seems to have deterred a great many investigators from making any attempt to determine how a polymorphic situation has come about. Many publications give lists of data for many human polymorphic systems from every corner of the globe, without referring to possible selective factors that may be maintaining them. So often the data collected are wholly geneticthus we may be given the haptoglobin and transferrin phenotypes, but we are seldom given the serum iron or the haemoglobin level.

The situation of polymorphisms in search of disease has a corollary: disease in which neither the number of genes involved nor their precise effects are known, but in which various facets suggest that a polymorphic situation may exist. Two such diseases may be mentioned herediabetes and schizophrenia: both are common; both are inherited conditions; both have interfered markedly (and still do, to an extent which is greater for schizophrenia) with biological fitness. Furthermore, in each condition mechanisms may exist to maintain the frequency of the responsible gene or genes: in diabetes the increase in prediabetic maternal fertility; in schizophrenia, increased resistance to stress (this does not seem to be estabished, but it remains a possibility).

Particular attention has been paid in this review 
to those polymorphisms in which selective factors are known to exist, or in which hypotheses have been constructed to explain a polymorphic situation. Data on some of the newly-discovered polymorphisms, not yet widely known, have also been included.

\section{A: BLOOD GROUP POLYMORPHISMS}

Three aspects of these complex polymorphisms are discussed here.

\section{I: Selective Forces Acting on $\mathrm{ABO}$ and $\mathrm{Rh}$ Blood Groups}

The subject of blood groups and natural selection is discussed (principally with reference to $\mathrm{ABO}$ and Rh) by Sheppard (1959), Reed (I96I), Clarke (I964), Chung and Morton (I96I) among many others. Among the selective factors the following call for consideration.

Prezygotic Selection. Three possible mechanisms exist: the first two mechanisms (which cannot be distinguished by testing) are confined to the heterozygous male.

Meiotic drive-unequal numbers of sperms carrying each type of allele.

Sperm competition-unequal opportunity for each type of sperm in the act of fertilization.

Thus with an AO father meiotic drive would mean more $A$ sperms than $O$ sperms (or vice versa) instead of equal numbers, i.e. a quantitative difference. Sperm competition would mean some intrinsic property favouring $A$ sperms at the expense of $O$ sperms (or vice versa), i.e. a qualitative difference.

Sperm incompatability-meaning, for example, that a sperm carrying an A gene coming in contact with cervical secretions containing anti-A would, thereby, be eliminated.

Matsunaga (1962b) provides evidence to support the hypothesis that prezygotic selection operates throughout so as to favour group $\mathrm{O}$ sperms: Morton (1965) does not consider the case proven.

Zygotic Selection. By this is meant the elimination of zygotes whose blood group is not that of the mother, by spontaneous abortion or by clinical haemolytic disease. That this occurs has been established by Chung and Morton (I96I), and Matsunaga (1962b). The loss is always of heterozygotes.

ABO Heterozygotes. The tendency for group $O$ sperms to be favoured must be balanced by disadvantages, otherwise blood group $O$ frequency would rise steadily. One disadvantage could occur in compatible heterozygote matings (e.g. $\mathrm{AO} \times \mathrm{AO}$ or $A B \times A B)$ if heterozygous offspring survived better than homozygous offspring.

Both Chung and Morton (I96I) and Matsunaga (1962b) found an excess of $A B$ children in $A B \times A B$ mating. The same might be true of $\mathrm{AO} \times \mathrm{AO}$ matings, but these are difficult to study because the AO phenotype cannot be established by simple testing as can the $\mathrm{AB}$ phenotype. Chung and Morton (I96I) stress that 'the genetic evidence strongly supports the assumption of Brues (1954) that the $A B O$ polymorphism is maintained because heterozygous advantage in compatible matings more than compensates for selection against heterozygotes in incompatible mating'. They further hold that 'the overall effect of maternal/foetal incompatibility is virtually the same for $\mathrm{O}, \mathrm{A}$, and $\mathrm{B}$ mothers, despite the fact that clinical haemolytic disease is almost restricted to children of $O$ mothers'. This should, perhaps, bring home the importance of not overestimating clinical haemolytic disease in considering selection and $\mathrm{ABO}$ blood groups.

Reed, Gershowitz, Soni, and Napier (1964) divide the reproductive indicator into several independent categories: the number of pregnancies, the proportion of pregnancies terminating in abortion or in stillbirth; and the proportion of liveborn children dying nonaccidentally under the age of 5 . These data were obtained from several hundred couples where the wife was over 40 , so that reproduction had virtually been completed. Six blood groups were studied in these couples (ABO, Rh, MN, Kell, Duffy, P) as was the secretor status.

An effect found to be significant at the $0.00 \mathrm{I}$ level was that $\mathrm{K}$ females ware found to have $\mathrm{m}$ ore pregnancies; at 0.005 level Group $\mathbf{N}$ females were more likely to be sterile (taken from amended data: Reed, 1965). Further studies of this type will plainly be required, both to substantiate or refute associations already found, and to extend the work to other blood groups. The task of determining the selective factors operating in the blood group polymorphisms is formidable indeed, particularly as interactions such as those between $\mathrm{ABO}$ and $\mathrm{Rh}$ may occur.

The Rh System. Newcombe (1963) and (1965) (amended data) has studied the $\mathrm{ABO}$ and $\mathrm{Rh}$ blood groups of mothers experiencing foetal death in New York, and has found that, with the exception of $\mathrm{AB} \mathrm{Rh}-$ mothers (who fare worst, being most likely to become $\mathrm{Rh}$ sensitized), the risk of foetal death to mothers over 30 rises as the number of antigenically active $\mathrm{ABO}$ and $\mathrm{Rh}$ alleles unrepresented in the mother's genotype rises (this number is 0 for $A B R h+$; $I$ for $A R h+$ and $B R h+$; 2 for $A R h-, B R h-$, and $O R h+$; and 3 for $O R h-$ ). 
In connexion with $\mathrm{Rh}$ incompatibility, a theoretical point that does not seem to be widely understood may be mentioned. If three genotypes appearing with frequencies $\mathrm{p}^{2}, \mathbf{2} \mathrm{pq}$, and $\mathrm{q}^{2}$ (corresponding to genes $\mathrm{p}$ and q) have relative selective advantages of $a, b$, and $c$, respectively, then for equilibrium: $\frac{p}{q}=\frac{a p^{2}+b p q}{b p q+c q^{2}}$

whence: $\frac{p}{q}=\frac{b-c}{b-a}$

This means that equilibrium can be achieved only if either $b-c$ and $b-a$ are both positive, or if they are both negative (because $p / q$ must be positive), i.e. if the heterozygote is either better or worse adapted than both the homozygotes. Now the baby afflicted by Rh haemolytic disease is always a heterozygote. It is, therefore, tempting to suggest that the disadvantage of this heterozgygote maintains a stable equilibrium. Unfortunately for such a simple hypothesis, this type of equilibrium is not stable. Stability in this type of situation (involving only a single locus) occurs only where there is heterozygous advantage. $\mathrm{Li}$ (1955) gives the mathematical proof of this.

The compensation phenomenon whereby mothers who have lost babies through $\mathrm{Rh}$ haemolytic disease produce more living babies than average seems established beyond doubt (for Caucasian mothers). Yet, as $\mathrm{Li}$ (1953) has pointed out, this cannot lead to a stable equilibrium, nor, of course, can genetic drift produce such a state of balance. $\mathrm{Li}$ (1955) suggests that a small heterozygous advantage (which he computes as 0.009 ) hardly detectable in ordinary genetic data will be sufficient to counterbalance the loss of those infants dying through $\mathrm{Rh}$ incompatibility and that a stable equilibrium could then be maintained. The nature of this advantage does not seem to have been determined as yet.

\section{II: Blood Groups and Disease}

Two aspects call for consideration:

Influence of Disease on Polymorphic Blood Group Systems. Does disease as it occurs today influence the $\mathrm{ABO}$ polymorphisms to an important degree? Available evidence seems to indicate that it does not. Has disease ever influenced the polymorphisms to an important degree? This is more difficult to answer, but the evidence, as far as such diseases as plague and smallpox (which have in the past been pandemic with a very high mortality) are concerned, is not convincing (Harris, 1963).

The decreasing likelihood of pandemic lethal infectious disease seems to make it less likely that the opportunity of relating blood groups to survival or death from such diseases will present itself.
Livingstone (1960) and Vogel, Pettenkofer, and Helmbold (1960) discuss this subject.

The effect of differences in incidence of duodenal ulcer, gastric carcinoma, and pernicious anaemia on the ABO polymorphism is infinitesimal compared with prenatal and early postnatal influences in maintaining the polymorphism, because these diseases affect biological fitness hardly at all. This is because mortality from these diseases chiefly occurs after the reproductive period is over.

Influence of Blood Groups on Disease Processes. Considerable interest has been taken in this subject since 1953 when Aird, Bentall, and Fraser Roberts showed an association between gastric carcinoma and blood group $A$.

A number of further associations have been established: pernicious anaemia and rheumatic fever with group A, and duodenal ulcer (and, to a lesser extent, gastric ulcer) with group $O$.

Group $\mathrm{O}$ subjects possess $\mathrm{H}$-antigen in the highest concentration, and Eichner, Finn, and Krevans (1963) suggest that this may explain the relation between this blood group and the titres of antibodies against the organism Esch. coli $086 \mathrm{~B} 7$, which $\mathrm{O}$ subjects possess at lower levels than $A, B$, and $A B$ subjects. If Esch. coli $086 \mathrm{~B} 7$ itself carries an ' $\mathrm{H}$-like' antigen, human subjects with group $\mathrm{H}$ antigen may fail to produce an antibody against the Esch. coli antigen and, hence, have lower antibody titres. A clear-cut disease association in this connexion has not yet been established.

Edwards (1965) emphasizes that achievements to date in this field should be kept in perspective. He calculates that if duodenal ulcer were purely the result of susceptibility inherited through the equal actions of a large number of genes of the potency and frequency of those at the ABO locus, then Ioo loci should be implicated. He goes on: 'before hereditary influences can be regarded as sufficiently marked to merit such attention a substantial contribution to total variance should be demonstrated'. It appears that ABO and secretor status contribute together about one-fortieth part of the total variance. Wiener (1965) in stronger vein writes 'studies on blood groups and disease have led to no useful result to date. No one has used blood-grouping in differential diagnosis.... No one has offered a satisfactory explanation how one's blood group could directly affect one's susceptibility to duodenal ulcer or to carcinoma, nor how one's blood group could affect one's personality or temperament' (one can infer that 'disease' in this quotation excludes haemolytic disease).

One might answer these arguments with a quotation from Ford (1965) - The association of polymorphisms with disease of any kind provides an example of the fact that controlling genes have important effects in addition to those by which they are normally recognised'. 


\section{III: Excess of Heterozygotes in MN Blood Group System}

This occurrence led Morton and Chung (1959) and Chung, Matsunaga, and Morton (196I) to conclude that data were consistent with heterozygote advantage apparently limited to children of $\mathrm{MN}$ mothers. This hypothesis would require that the $M N$ locus should have properties other than that of producing erythrocyte antigen. Hiraizumi (1964) proposed a different model to fit the data-whereby $\mathrm{N}$ has the lowest viability in the zygotic stage but has selective advantage in the prezygotic stage. Wiener, Gordon, and Wexler (1963) did not find the excess of heterozygotes, and criticized reports showing such excess on technical grounds. Levene, Hermoni, and Cividalli (1965) also failed to confirm the excess of heterozygotes in a study from Israel.

\section{B: PHENYLTHIOCARBUTAMIDE TASTING}

If one determines the highest dilution in which a test substance can just be tasted, one obtains a bimodal distribution showing that a polymorphism exists for the tasting of phenylthiocarbutamide (PTC), and a variety of other related compounds. These include 6-n-propylthiouracil (PROP) and other antithyroid substances. Individuals able to taste weak solutions are called tasters and those who require strong solutions are called nontasters. A pair of autosomal alleles $\mathrm{T}$ and $\mathrm{t}$ determine this effect. Subjects of the genotypes $T T$ and $T t$ are tasters, and of genotype $t t$, non-tasters. Testing does not distinguish between $T T$ and $T t$.

\section{Population Studies}

In European populations approximately $30 \%$ of people are non-tasters, which gives a gene frequency for ' $t$ ' of slightly over $50 \%$. The finding by Fisher, Ford, and Huxley in 1939 that $30 \%$ of chimpanzees are non-tasters led them to suggest that a balanced polymorphism had existed since the separation of anthropoid and human stocks. Unfortunately (for this hypothesis) large human populations with a very much lower percentage of non-tasters have been discovered (Barnicot, 1950).

Junqueira, Kalmus, and Wishart (1957) found no non-tasters in the Carajas Indians who live on the Island of Bananal in the Arguaia river, and Montenegro (1964) has also found low values for Brazilian Indians, with a marked sex difference, female non-tasters being much less common than males. This difference is statistically significant ( $p=0 \cdot 01$ ), and the author suggests the need to observe other Amazonian groups for this phenomenon. On the other hand, Das and Mukherjee (1964), and Das, Mukherjee, and Bhattacharjee (I963) have described remote tribes of the state of Orissa (India) where the proportion of tasters to non-tasters is approximately I to I. Other studies include those of Barnicot (1950) in African Negroes and Chinese: in both groups, non-tasters are less common than in European populations. This applies also to the Japanese survey of Lugg (I966) who criticizes the classical allelomorphic gene pair ( $T$ and $t$ ) hypothesis on the grounds that it inadequately explains available data, particularly a group of subjects with extremely high activities of taste which he has found.

\section{Mechanism of Differing Taste Sensitivity}

There is evidence to show that the saliva of nontasters can metabolize PROP and other thioureas more rapidly than the saliva of tasters (Griffin and Fischer, 1960; Fischer and Griffin, 1960). These investigations have further shown that this effect can be abolished by incubation of saliva with beef catalase, and the authors conclude that hydrogen peroxide is largely responsible for it. They point out that such an effect can only account for a twofold difference in the threshold for PROPwhereas the non-taster would require something like a sixteenfold lowering in the concentration which he can just appreciate to be converted to taster status. A physiochemical difference between the receptor sites on the tongue in tasters and nontasters seems to be necessary to explain the experimental findings. Many aspects of taste perception are dealt with by Fischer, Griffin, and Pasmanick (1963).

\section{Possible Selective Factors Maintaining Polymorphism}

Various publications have sought to establish or refute association between taster status and goitre, tuberculosis, diabetes, paralytic poliomyelitis, and duodenal ulcer, as well as in less common conditions, e.g. mucoviscidosis and mongolism.

(a) Goitre. Goitre has attracted most attention, and rightly so, for PTC and PROP are goitrogens. Clearly, if either consumption or metabolism of naturally-occurring goitrogens related to these substances differ between taster subjects and nontaster subjects, differences in goitre incidence may be expected. Harris, Kalmus, and Trotter (1949) showed an association between non-taster status and nodular goitre; Kitchin, Howel-Evans, Clarke, McConnell, and Sheppard (1959) have confirmed 
this association, particularly for English males, and Azevêdo, Krieger, Mi, and Morton (1965) have confirmed it in Brazil. The work of Kitchin et al. (1959) showed also a marked deficiency of nontasters among subjects with diffuse parenchymatous goitre. Covarrubias, Barzelatto, Stevenson, Bobadilla, Pardo, and Beckers (1965) could not confirm these associations for the Pewenche tribe of Chilean Indians, nor could Luca and Cramarossa (1965) in Central Italy, nor Memoria (1959) in Brazil, nor Fraser (1963) in England. However, in an endemic goitre area of Israel (non-toxic nodular goitre being the type of goitre occurring), a significant increase in numbers of non-tasters was found among goitrous as compared with non-goitrous children (Brand, 1963). It seems that present evidence does not lead to the establishment of simple rules relating taster status to thyroid disease.

Where an association has been established, how can such an association come about? Clements (1960) has described a sequence of events to account for the appearance of goitre in newly-settled land. According to this, cows first graze on indigenous grasses, while other land is cultivated for crops. When this is allowed to lie fallow, infestation with weeds such as Raphanus raphanistrum and Brassica campestris rapidly follows, and these weeds contain significant concentrations of bitter-tasting goitrogenic compounds which may be present in milk. If 'taster' children are deterred from drinking such milk by its taste, they would, thereby, avoid consumption of goitrogenic substances and be less likely to develop this type of goitre. (There is evidence (Fischer, Griffin, England, and Garn, 196I) to suggest that 'tasters' have far more food dislikes than non-tasters, and tasters, by rejecting a variety of foods, may relatively reduce their consumption of bitter and pharmacologically active substances.)

The development of a goitre is not, per se, evidence that selective forces are operating against its possessor's biological fitness, though obvious cosmetic disadvantage is one simply understood factor that could operate. Non-tasters are also at a disadvantage in that a higher proportion of their children will suffer athyreotic cretinism than would be expected by chance (Fraser, I96I).

(b) Other Diseases. A clear relation between diabetes and PTC 'non-taster' status does not seem to have been established. Harris et al. (1949) failed to confirm a relationship put forward by Terry and Segall (1947). A recent paper showing a slight, but significant, hyposensitivity of diabetics to the taste of dextrose has been published by Schelling, Tétreault, Lasagna, and Davis (1965). This sensitivity is said to be controlled by a locus different from that of PTC tasting (Fischer et al., 1963).

In 1956, Saldanha, working in Brazil, produced data strongly supporting the hypothesis that there $\stackrel{\$}{\triangle}$ was a differentially increased mortality from juvenile $\stackrel{\oplus}{\stackrel{\oplus}{.}}$ tuberculosis in 'non-tasters'. If this were confirmed, $\vec{\Rightarrow}$ it would provide evidence of a selective mechanism $\stackrel{?}{+}$ operating against non-tasters. This work has been $\bar{c}$ criticized by Akesson (1959) on the grounds that the $\frac{\bar{\sigma}}{\bar{N}}$. population studied by Saldanha was not homo- $\frac{\sigma}{\sigma}$ geneous so that socio-economic stratification factors $\varrho$ were not avoided. Akesson's own work does not show any significant correlation between the $\vec{\circ}$ occurrence of tuberculosis (or of diabetes) and the $\rightarrow$ taster phenotype.

A paper on the increased incidence of taster status in patients with non-fatal paralytic polio-0ิ myelitis (Brand, 1964) is based on a study carried + out in Israel. The population studied was a mixture of European, Asian, and North African immigrants, $\overrightarrow{+}$ or the first generation offspring of such, and is open to the same criticism as that of Saldanhamentioned above. Kaplan, Fischer, Glanville, $\frac{3}{\mathrm{~g}}$ Powell, Kamionkowski, and Fleshler (1964) have produced evidence of an increase in the proportion of tasters in patients with duodenal (but not with gastric) ulcer. This cannot be related to differences. in age, smoking habits, race, or diet, between ulcer patients and non-ulcer controls. For reasons mentioned in the blood group section of this review, such an association is not, of itself, likely to operate on biological fitness to a marked extent.

\section{COLOUR BLINDNESS POLYMORPHISM}

Colour blindness is of interest both to the animal and to the human geneticist. The former will be fascinated by the uneven distribution of colour 3 . vision in the animal kingdom (e.g. men and butterflies have colour vision whereas dogs do not). The human geneticist will find it of special interest, 0 because colour blindness was one of the earliest sex-linked anomalies to be documented.

Definitions. When red, green, and blue light are all $\mathrm{N}$ projected on a single screen, the triple mixture of these $\mathrm{N}$ colours will make a white light. A person with normal $\mathrm{N}$ colour vision will require a particular intensity ratio of $\omega$ red: green: blue, in order to see white; he is a normal trichromat. Some people need a more than usualo intensity of one particular colour of light to see white $\frac{\bar{\Phi}}{\mathbb{}}$ light-these are 'anomalous' trichromats (hence the : names protanomaly and deuteranomaly, see below).

A further group of people need only two of the three $\bar{O}$ colours to match white, and these people are dichromats. Deuteranopia and protanopia (see below) are the commonest forms of dichromatic vision.

Finally, a few people will match a single colour against 
white light-these are monochromats: they perceive no hues seeing only white and grey.

A useful classification is as follows:

\begin{tabular}{lcc}
\hline Trichromatic vision & $\begin{array}{c}\text { Dichromatic } \\
\text { vision }\end{array}$ & $\begin{array}{c}\text { Monochromatic } \\
\text { vision } \\
\text { (not subdivided) }\end{array}$ \\
\hline $\begin{array}{l}\text { Normal colour vision } \\
\text { Protanomaly } \\
\text { Deuteranomaly }\end{array}$ & $\begin{array}{c}\text { Protanopia } \\
\text { Deuteranopia } \\
\text { Tritanopia }\end{array}$ \\
\hline
\end{tabular}

Protanomaly and protanopia are often grouped together under the title 'protan colour blindness', and the primary dysfunction is inability to recognize red light. Deuteranomaly and deuteranopia are similarly grouped as deuteran colour blindness, the difficulty being primarily with the recognition of green colours. Deuteranomaly is the commonest abnormality accounting for (very approximately) $60 \%$ of all cases. In the female, deuteranomaly is dominant to deuteranopia, should the unusual circumstance of inheritance of an abnormal X chromosome from each parent occur.

Tritanopia, which is manif zsted by difficulty in blue/ yellow discrimination, is very rare.

Kalmus' monograph (1965) gives a comprehensive account of the methods used currently in the investigation of colour blindness.

\section{Two Polymorphisms}

Red/green colour blindness includes deuteranomaly, deuteranopia, protanomaly, and protanopia. However useful the term red/green colour blindness is in everyday usage, the expression oversimplifies the position when one is considering polymorphisms, for it seems increasingly likely that there are two polymorphisms-normal/deuteran and normal/protan with independent loci on the $\mathrm{X}$ chromosome. That there are at least 2 genetic loci for these two polymorphisms is suggested by evidence from a variety of sources.

Linkage Studies. Siniscalco, Filippi, and Latte (1964) carried out linkage studies on a Sardinian population and concluded that the sequence for the following $3 \mathrm{X}$ chromosome genes was:

\section{deuteran: G6PD: protan,}

though this does not agree with the findings of Jackson, Symon, and Mann (1964) who have the colour vision loci close together and not separated by the G6PD locus.

Family Studies. Siniscalco et al. quote a family studied by VanderDonck and Verriest (1960) in which two deuteranopic, one protanomalous, and two normal sons occur in the same family. This seemed best explained by assuming that the mother of the propositi was a heterozygote for genes at the protan and deuteran loci, so that the two normal sons had to be considered as recombinants. A further family study giving additional support to the two loci theory is given by Dreyer and Goldschmidt (1965).

Comparison of Data for Males and Females on a Single Gene and a Double Gene Hypothesis. If we take $x$ as the frequency of the protan defect in males and $y$ as the frequency of the deuteran defect in males, the total protan/deuteran defect frequency in females is given by $\left(x^{2}+y^{2}\right)$ on the 'two gene loci' hypothesis.

If we treat the data simply as that for red/green colour blindness, the frequency for males is $x+y$; for females $(x+y)^{2}$. The lower value $x^{2}+y^{2}$ agrees better with population study findings.

The scarcity of double hemizygotes for red-green defects (which has been calculated to be about $I$ in 800 of all males) is worth noting. Pickford (1962) illustrates this problem and discusses it further in a Ciba Foundation symposium (I965), p.238, which is entirely devoted to the subject of colour vision. In this latter article, Pickford distinguishes three different subtypes of defect for each of the protan and deuteran types-protanopia, extreme protanomaly, and simple protanomaly, with inheritance true to type. In the discussion following his article, he says that, 'there must be many more than six genes ...' (i.e. with influence on red/green colour vision), and if this view is correct, linkage studies may well show discrepancies due simply to heterogeneity between the populations being studied.

\section{Population Studies}

Post (1962) lists a large number of studies up to 1962. More recent data include those of Thuline (1964) from U.S.A.; Kalmus, De Garay, Rodarte, and Cobo (1964) from rural Mexico; Plato, Cruz, and Kurland (1964) from the Western Pacific; and Dutta (I966) from India.

Post divided the data in his paper as applying to three categories. A: hunters and food gatherers; $C$ : populations farthest removed from hunters in time and habitat; and B: an intermediate category.

Summing the data from all populations in each subgroup, he finds the frequency of colour blindness in Group A to be 0.02 ; in Group B, 0.033 ; and in group $\mathrm{C}$, around 0.08 . He considers that the evidence fits in with the hypothesis that there has been a relaxation of selection against the 'colour blindness' genes in the populations of group C. Dutta's analysis (1966) of Indian data gives general support to this hypothesis. Post (1965) calculates the 
selection rate for category A subjects to be the same for protans and deuterans, namely 0.06 . Post considers that selection against young boys who have not learned to compensate for their defect and who have not had reproductive opportunity because of their age may account for this high figure, as may the rewarding of successful (normal-sighted) hunters and warriors in primitive societies with more wives (Neel and Post, 1963). Ford (1965) has criticized Post's hypothesis on the grounds that the gene could not have reached the status of a polymorphism unless it were associated with advantages as well as disadvantages (though the nature of these advantages is quite unknown). Although it is well known that persons with colour blindness may show superiority in recognizing camouflage, any effect resulting from this is likely to adjust (rather than maintain) the polymorphism in any given habitat, for it has yet to be shown that a habitat exists in which the colour-blind person has over-all visual advantage over a normal person. Post (1962) suggests that relaxation of selection in European communities may have been in operation since the introduction of domestic animals and agriculture 120 generations ago.

\section{Selection in Civilized Communities}

Gramberg-Danielson (196I) states that the theoretical implication that colour defective persons should be confused by the colour of a traffic light is practically insignificant, but he 'welcomes a decision of German traffic authorities according to which the green of a traffic light will tend in the future towards the more conspicuous green-blue'.

One wonders whether the selection of people with normal colour vision for jobs where this is important (e.g. combatant servicemen, airline pilots, engine drivers etc.), but where more risk is entailed than in the average job, may not constitute a slight advantage for the colour-blindness genes.

\section{D: HUMAN EAR-WAX}

Little appears to have been published on the subject of ear-wax since a review by Matsunaga (1962a). Two types, wet and dry, differ in physical properties, the former having a sticky consistency. Chemical differences plainly exist but full characterization of these differences does not seem to have been achieved.

If two autosomal alleles $W$ and $w$ are postulated, most reports are consistent with the hypothesis that wet cerumen corresponds to genotype $\mathrm{WW}$ or $\mathrm{Ww}$; dry cerumen to ww. It is remarkable that in various human populations $W$ and $w$ vary in frequency by almost as much variation as is possible: thus, in the
Northern Chinese, the frequency of $W$ equals $0.02 I I ;$ at the other extreme, W equals 0.9306 fo American Negroes.

An association between wet cerumen and the development of apocrine sweat glands has beer noted (Matsunaga (1962a) gives references). It has been suggested that differing reactions to environ $\frac{5}{5}$ mental changes may be associated with possessiom of these glands. Presumably this would meaw selection favouring the gene $\mathrm{W}$ where possession of the sweat glands conferred advantage. No sug:gestions as to possible advantages of $\mathrm{w}$ have been made.

\section{E: $\beta$ AMINO ISOBUTYRIC ACIDURIA}

There do not appear to have been many contri butions to the genetics of this condition since the review by Gartler (I96I). A percentage of the popu lation (about 10\% for English white individuals) are high excretors of this amino acid in the urine, these subjects being homozygotes for a recessive gene? Low excretors are either heterozygotes or homo $=$ zygotes for the corresponding dominant allele: Malignant disease, and treatment thereof, and impaired liver function are causes of increased levels of urinary BAIB which do not depend on genetic control.

Armstrong, Yates, Kakimoto, Taniguchi, and Kappe⿻ (1963) put forward the interesting hypothesis that high BAIB excretion may enable essential amino acids (oo other essential food factors) to be conserved by a renaP tubular counterbalancing mechanism. They sugges that this conservation might be beneficial, particularly? under conditions of famine. This advantage, which would apply to the homzygote for 'high excretor' genes, would not lead to a stable polymorphism, but a transient polymorphism could be produced if famine conditions. were to persist in a population long enough for thiso gene (introduced by mutation) gradually to increase in frequency. Armstrong has investigated his hypothesiso by comparing the urinary output of various amino acids in high and low BAIB excretors but has not detected anyo significant differences.

High excretors of BAIB appear to be deficient in an enzyme which further metabolizes BAIB and they simply excrete it unchanged. Gartler (I96I) ${ }^{C}$ suggests that, as BAIB formation is essentially a? waste pathway, high urinary excretion may simply represent a shortening of the pathway, and may, $\mathbb{\infty}$ thereby, have some selective advantage and be ${ }^{-}$ increasing in frequency. A state of 'enzyme $\frac{}{-}$ deficiency' must not automatically be considered $\frac{\vec{D}}{\mathrm{D}}$ as indicating a biological deficit: proteins evolve $\frac{\odot}{\Phi}$ and those that cease to confer any benefit will tend $\stackrel{\circ}{2}$ to become extinct. 


\section{F: HAEMOGLOBINOPATHIES}

Huehns and Shooter (1965) have recently reviewed in this Journal a great deal of data on the structure and biosynthesis of haemoglobin and its variants and the genetics thereof. Only data relating to the polymorphisms which involve variant haemoglobins will be touched on here.

The major part of haemoglobin consists of the $A_{1}$ portion. The haemoglobin $A_{1}$ molecule contains, in the globin fraction, four polypeptide chains, two $\alpha$ and two $\beta$. Each pair is under the control of a pair of alleles. Abnormality of the $\alpha$ chain occurs in $\alpha$-thalassaemia and of the $\beta$-chain in $\beta$-thalassaemia, sickle cell anaemia, and $\mathrm{Hb} \mathrm{C}$ and $\mathrm{Hb} \mathrm{E}$ disease.

Five abnormal haemoglobins are present in various human populations in a frequency so high as to constitute examples of unquestionable polymorphism. The genes responsible are the following.

(I) Sickle cell gene-up to $40 \%$ trait carrier in some Eastern African tribes (Allison, 1954).

(2) The $\beta$-thalassaemia gene-up to $20 \%$ trajt carrier frequency in Rhodes (Barnicot, Allison, Blumberg, Deliyannis, Krimbas, and Ballas, 1963), and in Sardinia and Italy (Carcassi, Ceppellini, and Pitzus, 1957).

(3) Haemoglobin C gene-30\% in Northern Ghana (Edington and Lehmann, 1956).

(4) Haemoglobin E gene-almost $20 \%$ in Thailand (Kruatrachue, Charoenlarp, Chongsuphajaisiddhi, and Harinasuta, 1962).

(5) The $\alpha$-thalassaemia gene.

In each of these first four cases the polymorphisms have been reported in several areas, the percentages quoted being at the upper end of the frequency range.

Recent publications which include data on the population genetics of the haemoglobinopathies include those of Allison (1965) and Lehmann and Huntsman (1966).

\section{I: Sickle Cell Polymorphism}

With the sickle cell gene $\left(H b_{\beta} S\right)$, the protection afforded to the heretozygote $H b_{\beta} s / H b_{\beta} A$ against falciparum malaria, increasing biological fitness, provides an example of heterozygous advantage which few would question. Allison (1965) has tabulated data showing that the ratio of sickling trait in older children and adults (together) to that in young children exceeds unity. This rise is explained as being due to the loss of $\mathrm{Hb}_{\beta}{ }^{A}$ homozygotes from malaria, an event most likely to happen in the first four years of life before acquired immunity affords substantial protection. This hetero- zygote advantage is balanced against the loss of large numbers of the $H b_{\beta} s / H b_{\beta} s$ homozygotes, so that the fitness of the latter is very low in Africa. However, Anderson, Went, MacIver, and Dixon (1960) and Jonxis (1965) report that some West Indian sickle cell homozygotes may survive to reproductive age.

Additional evidence for the malaria hypothesis is: (a) the demonstration of lower $P$. falciparum parasite rates and counts in heterozygote children $\left(\mathrm{Hb}_{\beta} \mathrm{S}\right.$ $H b_{\beta} A$ ) than in non-sickling children; (b) the rarity of sickling in fatal malarial infection; and (c) the distribution of the sickle cell gene, which does not attain high frequency outside areas where malaria is hyperendemic or holoendemic, except in a small area near Lake Chad (Nigeria) where a frequency of $30 \%$ was reported by Roberts and Boyo (1960), and where malaria is only epidemic.

As far as the effects of the trait on fertility are concerned, Allison summarizes the situation thus: 'increased female fecundity is far from adequate to explain the persistence of the sickle cell gene at the observed frequencies in Africa'. However, Firschein (I96I) has reported that in the Black Caribs of British Honduras (who are of African Negro origin), the fertility roati of sickle cell trait mothers to normal is sufficient to maintain the gene in the absence of differential mortality due to malaria in infancy. This effect is suggested as being prenatal, due to interruption of pregnancy in non-sicklers by malaria. However, other reports (from Africa), e.g. those of Burke, De Bock, and De Wolf (1958), Roberts and Boyo (1960), and Delbrouck (1958), have not given such clear-cut results.

\section{II: $\beta$-Thalassaemia}

As far as $\beta$-thalassaemia is concerned, Fraser, Stamatoyannopoulos, Kattamis, Loukopoulos, Defaranas, Kitsos, Zannos-Mariolea, Choremis, Fessas, and Motulsky (I964) conclude that 'although it is likely that falciparum malaria also plays a role in the maintenance of thalassaemia frequencies the evidence is not as good as for sickling and G-6 Pd deficiency'. Thus, though Carcassi et al. (1957) noted a higher incidence of $\beta$-thalassaemia in the low-lying marshy areas of Sardinia than in the mountainous areas where malaria has been less common, Choremis, Fessas, Kattamis, Stamatoyannopoulos, Zannos-Mariolea, Karaklis, and Belios (1963) found a non-significant gene frequency difference between schoolboy populations grouped according to the altitude at which they lived in a region of Greece which had been malarious.

Increased iron absorption from the intestine found in thalassaemia homozygotes by Witzleben 
and Wyatt (196I) is not present in the heterozygote (Bannerman, 1962), and the suggestion of Haldane (1949) that enhanced absorption might protect heterozygotes against iron-deficiency anaemia and, thus, confer advantage cannot be substantiated.

\section{III: Haemoglobin C}

Homozygotes for the $H b_{\beta} C$ gene, unlike those for the $H b_{\beta} S$ gene with which $H b_{\beta} C$ is widely associated in West Africa, are not afflicted by a disease which is lethal before the reproductive period. Their condition will only rarely interfere with biological fitness. This abnormal gene is found in West Africa. Cabannes (1965) tabulates the frequencies of the gene which does not appear to spread to the East of the Niger river. No rule of thumb can be given for the occurrence together of $\mathrm{Hb}_{\beta} \mathrm{S}$ and $\mathrm{Hb}{ }_{\beta} \mathrm{C}$ genes in populations-there is neither a direct nor an inverse relation over-all. Cabannes provides an analysis of available data. It seems likely that a state of stable equilibrium has not been reached in all the populations where both these genes occur.

The following data on haemoglobin $\mathrm{C}$ are of interest.

(a) Evidence in favour of protection of the heterozygotes for $\mathrm{Hb}_{\beta} \mathrm{C}$ against $P$. falciparum does not seem completely conclusive, though Thompson (1962) provides evidence showing a lower mean parasite density for AC than for AA phenotypes in Ghanaian children aged I-6 years, which is significant at the 0.01 level.

(b) Using data from North Ghana, Edington and Laing (1957) calculate fitness ratios for $\mathrm{Hb}_{\beta} \mathrm{A} / \mathrm{Hb}_{\beta} \mathrm{A}$ and $\mathrm{Hb}_{\beta} \mathrm{A} / \mathrm{Hb}_{\beta} \mathrm{C}$ as 0.976 and $\mathrm{I} \cdot \mathrm{IO} 3$, respectively.

(c) Penrose, Smith, and Sprott (1956) reach the conclusion that a stable equilibrium between $\mathrm{Hb}_{\beta} \mathrm{s}, \mathrm{Hb}_{\beta} \mathrm{C}$ and $\mathrm{Hb}_{\beta} \mathrm{A}$ could be reached, provided $\mathrm{Hb}_{\beta} \mathrm{A} / \mathrm{Hb}_{\beta} \mathrm{S}$ and $\mathrm{Hb}_{\beta} \mathrm{A} / \mathrm{Hb}_{\beta} \mathrm{C}$ heterozygotes are at advantage.

(d) Went (196I), in an unconfirmed report, has drawn attention to a departure from expected Mendelian ratios among offspring of Jamaican $\mathrm{Hb}_{\beta} \mathrm{A} / \mathrm{Hb}_{\beta} \mathrm{C}$ mothers mated with $\mathrm{Hb}_{\beta}{ }^{\mathrm{A}} / \mathrm{Hb}_{\beta} \mathrm{A}$ fathers; $24 \mathrm{Hb}_{\beta}{ }^{\mathrm{A}} / \mathrm{Hb}_{\beta} \mathrm{C}$ offspring, as compared with $7 \mathrm{Hb}_{\beta} \mathrm{A} / \mathrm{Hb}_{\beta} \mathrm{A}(\mathrm{p}<0.0 \mathrm{I})$, were produced. As this might provide an example of differential gametic selection or survival, further data would be worth collecting to see whether or not this observation can be substantiated.

Fullerton, Hendrickse, and Watson Williams (1965) report a $10 \%$ mortality for haemoglobin $S C$ disease (genotype $\mathrm{Hb}_{\beta} \mathrm{sHb} \mathrm{H}_{\beta} \mathrm{C}$ ) in pregnancy, from Ibadan, Nigeria, mortality being much higher in emergency admissions. Megaloblastic anaemia due to folic acid deficiency was the largest single factor associated with this mortality. It is presumed that dietary intake cannot cope with the double stress of extra erythropoiesis and extra requirements due to the pregnancy.

\section{IV: Haemoglobin E}

Data on haemoglobin $\mathrm{E}$ do not seem to be ade $\stackrel{\mathbb{P}}{=}$ quate for the assessment of a 'malaria hypothesis $\frac{5}{5}$ Protection against malaria has yet to be shown The gene has attained high frequency in South East Asia (Lie-Injo Luan Eng (1964) tabulates this an area in which Allison (1957) has suggested that malaria might be involved in maintaining a polyo morphism. Further data on this subject and on the interaction between the genes for $\beta$ thalassaemi $\oplus$ and haemoglobin $\mathrm{E}$ (similar to that between $\mathrm{Hb}_{\beta}$ and $\mathrm{Hb}_{\beta} \mathrm{C}$ discussed above) in the Thai populatiof are given by Flatz, Pik, and Sringam (I965a, b)

\section{V: $\alpha$-Thalassaemia}

The $\alpha$-thalassaemia gene is probably associate with intrauterine death in the homozygous state and in Negro and Oriental populations the carrier state may reach levels of $5 \%$. However, difficulty ip recognizing the heterozygous state in adults ha\$ precluded accurate population studies. Weatheralf (I965) discusses this problem.

It is clear that in the case of the sickle cell gene substantial evidence exists for the operation of malaria as a selective force. In other haemoglobino pathies (and in G6PD deficiency) selection duo to malaria may be less intense and, therefore more difficult to demonstrate. Nevertheless the indirect evidence provided by distribution studie suggests malaria as a selective force for these con? ditions also.

\section{G: ENZYME POLYMORPHISMS}

The known number of polymorphisms relating to human enzymes has increased rapidly over the past few years. Where polymorphic enzymes are present in the red cells or serum, direct measure ment of enzyme activity coupled with separatiog of the individual components by electrophoresi 존. affords a convenient method of study. The numbefs of such serum and red cell enzymes which have been shown to be polymorphic suggests that som? of the parenchymal enzymes may be polymorphiev also. Investigation of these is hampered by diffe culty in obtaining them for study from organ that are inaccessible except at operation or necropsyof

Pharmacogenetics (which may be defined as the study of genetically determined variations in animat species which are revealed by the effects of drugs offers one solution to this difficulty (see Evans 1962, 1963). This approach has met with usefuf results: for example, the acetylation polymorphisn? 
has been investigated largely by means of a pharmacogenetic approach.

Electrophoretically-delineated polymorphisms may be divided into two types: those in which there is a quantitative alteration in enzyme activity and those in which enzyme activity remains at a normal level. In the latter case, selective forces may still be able to exert a direct effect, e.g. naturally-occurring enzyme inhibitors often have altered properties of inhibition when the structure of the enzyme on which they act is altered.

Indirect effects, via some other property determined by the polymorphic genes, may also explain some of the enzyme polymorphisms in which, with the exception of G6PD, knowledge of selective forces is at present virtually non-existent.

Eight enzyme systems are dealt with in this section.

\section{I: Erythrocyte Glucose-6-Phosphate Dehydrogenase Deficiencies}

\section{General Considerations.}

Biochemistry. Red cell glucose-6-phosphate dehydrogenase (G6PD) is an enzyme concerned in the oxidative metabolism of red cell glucose. This oxidative reaction forms part of the pentosemonophosphate shunt, a relatively minor portion of glucose being dealt with by this shunt normally. It is thought that the presence of a certain amount of reduced glutathione may render haemoglobin more resistant to oxidant compounds (e.g. the sulphonamides), and that G6PD is necessary for the production of this reduced glutathione. A simple reaction scheme is as follows:

Glu. 6 phosphate + TPN $\underset{\text { G6PD }}{\longrightarrow}$ Gluc. phosphogluconate + TPNH $+\mathrm{H}$ Oxidized glutathione $\stackrel{\text { TPNH }}{\longrightarrow}$ reduced glutathione

Reduced glutathione is necessary for optimal metabolism of the Plasmodium falciparum parasite (Motulsky, Kraut, Thieme, and Musto, 1959).

Techniques. Motulsky (1965) gives an account of test systems for G6PD activity.

Distribution. Many populations exist in which the frequency of a single type of G6PD deficiency attains a frequency (often well over $20 \%$ ) so high that a genetic polymorphism must be postulated to occur. The chief areas of distribution of the deficiency are West and Central Africa, India, parts of South East Asia, the Philippines, and some of the countries around the Mediterranean.

Genetics. The loci determining normal and variant enzymes are on the $\mathbf{X}$ chromosome. Therefore, the situation has to be considered separately for the two sexes. If $\mathrm{X}_{1}$ is a chromosome bearing a gene determining deficiency and $\mathrm{X}$ a chromosome with the normal gene, then males can be normal (XY) or affected $\left(X_{1} Y=\right.$ the affected hemizygote); females can be normal $(X X)$, heterozygote $\left(X_{1} X\right)$, or affected $\left(X_{1} X_{1}=\right.$ the affected homozygote).

Clinical Picture. G6PD deficient people $\left(X_{1} Y\right.$ and $X_{1} X_{1}$ ), particularly if non-Negroes, are subject to neonatal jaundice and kernikterus; $\mathrm{Rh}$ haemolytic disease may be more lethal when combined with G6PD deficiency. Haemolytic episodes may occur with drugs, e.g. antimalarials, sulphonamides, sulphones, antipyretics, nitrofurans, etc., and with foods such as the fava bean (or with fava pollen), certain peas, and several other vegetables, and during viral or bacterial infections. These more severe haemolytic episodes may be set against a background of chronic haemolytic anaemia, particularly in Northern European and Japanese populations.

The Malaria Hypothesis. It seems likely that decreased morbidity from malaria in the heterozygote female has become balanced against loss of hemizygote affected males and homozygote affected females.

The 'malaria' hypothesis in relation to G6PD deficiency has been extensively reviewed. Recent reviews include those of Motulsky (1964, 1965). Motulsky and Campbell-Kraut (I962) have maps showing that the distribution of G6PD deficiency has marked similarity to the distribution of falciparum malaria. There are a number of reports showing a high incidence of G6PD deficiency in low-lying malarious areas with a much lower incidence of malaria and G6PD deficiency in highland areas only a few miles away. Kidson and Gorman (1962) have challenged this concept. One fact against the 'malaria' hypothesis used by them, namely the low incidence of G6PD deficiency in populations such as the Malays and Indonesians where malaria has been holoendemic, has prompted a reply from Allison (1963) who points out that the only convincing argument against the hypothesis would be the presence of high frequencies of G6PD deficiency in populations known to have lived in an environment long free of malaria. Kidson and Gorman. on the basis of data obtained from New Guinea and using additional genetic parameters also suggest that spread of a genetic trait into the uplands may have occurred from a 'large gene pool on the coast near the river mouth with dilution and diminution of gene frequency along the valley and into the highlands'. This may indeed be so, but one would wish to know how such a gene pool originally arose. 
Allison points out that though other parasitic diseases and nutritional inadequacies might account for different G6PD deficiency rates, no specific alternative hypothesis to the malaria one has yet been put forward.

Although data regarding malaria parasite counts in children with enzyme deficiency have been conflicting, the bulk of evidence suggests that malarial infection may be less severe in small children (who will have incomplete acquired immunity) with G6PD deficiency. Powell and Brewer (1965) infected 16 adult Negro males ( 8 being G6PD deficient but symptom-free, and 8 normal) with $P$. falciparum, and could detect no difference in the attacks of malaria so produced. As they point out, such experiments do not shed light on what obtains when there are very high levels of parasitaemia attended by substantial mortality. The performance, under laboratory-controlled conditions, of experiments designed to derive data on differential human mortality has certain ethical difficulties.

Ascertainment of the Heterozygote. In detecting the heterozygote female, practical difficulties are encountered if an assay method is used. The methaemoglobin reduction test will identify approximately $80 \%$ of heterozygotes (Tarlov, Brewer, Carson, and Alving, 1962), but errors may be made in both directions, genetically-proven heterozygotes giving results in the normal or the deficient ranges instead of in an intermediate category (Trujillo, Fairbanks, Ohno, and Beutler, 1961). The situation is technically easier in nonNegro populations (e.g. in Sardinia), than in Negroes, because the variety of deficiency encountered in the former is such as to cause greater deviation of G6PD activity from normal in the heterozygous female. Davidson, Childs, and Siniscalco (1964) give further data on this subject.

There are, thus, practical difficulties of ascertainment in investigating heterozygote advantage in G6PD deficiency. Data on malarial mortality and fertility in heterozygotes do not yet appear to be available (Motulsky, 1964).

Haemoglobinopathies and G6PD Deficiency. Livingstone (1964) discusses the population dynamics of abnormal haemoglobin and G6PD deficiency genes. He points out that, in contrast to the haemoglobinopathy genes, G6PD 'deficiency' genes do not have a great influence on biological fitness. Therefore, it takes much longer for the incidence of the latter genes to increase. His conclusions, evidently somewhat conjectural, suggest that the state of attainment of equilibrium for the G6PD deficiency gene may have occupied a time amounting to some 200 generations or so.

Heterogeneity of G6PD Deficiency. There is considerable evidence to indicate that the deficiency is not the result of an identical mutation in various affected populations. This heterogeneity is manifest in variations in degree of decrease of enzyme activity in different cell types; in differences in chemical properties of the enzyme; and in dif- $\overrightarrow{0}$ ferences in susceptibility to various agents capable of inducing haemolysis. Marks and Banks (1965) $\vec{\omega}$ tabulate data relating to the properties of eight differing variant enzymes with reduced activity.

Variation without Deficiency. Kirkman and Hendrickson (1963) give further details of a system described by Porter, Boyer, Schulze, and McKusick 을 (196I), in which an electrophoretic variant unaccompanied by diminished activity is described. Data from Davidson et al. (1964), showing correlation between erythrocyte G6PD levels in normal male sibs, provide further evidence sug- $\mathscr{G}$ gestive of a number of normal alleles.

\section{II: Erythrocyte 6-Phosphogluconate Dehydrogenase Polymorphism}

6-phosphogluconate dehydrogenase (6PGD) is an enzyme on the pentose monophosphate shunt, a property which it shares with G6PD (q.v.)

Glucose-6-phosphate $\stackrel{\text { G6PD }}{\longrightarrow}$ 6-phosphogluconate

6-phosphogluconate $\stackrel{6 \mathrm{PGD}}{\longrightarrow}$ 6-phospho-3-ketogluconate

Values of 6PGD can be determined by the method of Zinkham and Lenhard (1959). The common variant to be discussed here does not confer a state of deficiency (though true deficiency can occur). In this respect, of course, 6PGD differs from G6PD.

There has been a recent survey on 6PGD by Dern, Brewer, Tashian, and Shows (1966). They o examined haemolysates by starch gel electrophoresis $N$ in American subjects, and $6.1 \%$ of an abnormal $N$ phenotype called $\mathrm{AB}$ was found among Negro subjects; this was also found in 1 of 58 Caucasian subjects. Fildes and Parr (I963), working in London, found 10 examples of $\mathrm{AB}$ in 150 blood $\stackrel{\Phi^{+}}{+}$ samples from adults 'mostly of European descent'. ' Parr and Fitch (1964) found the common variant in 0 $I$ in every 27 of a sample of the population of $\underset{\mathbb{D}}{\vec{D}}$ London E.I, so that no gross differences seem to exist between American and British data. Both sexes are affected. Fildes and Parr (1964) suggest a 
two allele system with two genes $\alpha$ and $\beta$. Genotypes $\alpha \alpha$ and $\alpha \beta$ thus correspond to the phenotypes $A$ and $A B$ (AB subjects possess both $A$ and $B$ protein bands). [Note added in proof: Further details of electrophoretic properties of 6PGD, including phenotype $B$, can be found in a paper by J. E. Bowman, P. E. Carson, H. Frischer, and A. L. de Garay in Nature (Lond.) (1966) 210, 8I I.]

\section{III: Erythrocyte Phosphoglucomutase Polymorphism}

Phosphoglucomutase (PGM) plays an important part in carbohydrate metabolism. It is a phosphotransferase which catalyses the transfer of a phosphate group between the I- and the 6-position of glucose. PGM is widely distributed in the body. Although the polymorphism to be described is studied most conveniently in red blood cells it can be shown to exist in a variety of tissues.

Spencer, Hopkinson, and Harris (1964) have studied this enzyme in human red cell lysates by means of starch gel electrophoresis. At least seven enzymes having PGM activity can be distinguished in human tissues. These have been labelled ' $a$ ' to ' $g$ ' according to the rate of migration on starch gel, ' $a$ ' being the slowest running component of the system, ' $g$ ' the fastest. (Rare abnormalities of ' $e$ ', ' $\mathrm{f}$ ', and ' $\mathrm{g}$ ' have been described by Hopkinson and Harris (1965).) Spencer et al. have shown that a polymorphism exists, characterized by the presence of 3 phenotypes, I, 2-I, and 2. Subjects with phenotype I possess PGM in the ' $a$ ' and ' $c$ ' positions (as well as ' $e$ ', ' $f$ ', and ' $g$ '); with phenotype 2-I, PGM in all positions ' $a$ ' to ' $g$ '; and with phenotype 2 , PGM in positions ' $b$ ' and ' $d$ ', as well as ' $e$ ', ' $f$ ', and ' $g$ '. Data obtained from 338 unrelated English adults show frequencies for the three types $I, 2-I$, and 2 to be $0.550,0.376$, and 0.074 , respectively. Family studies are consistent with there being two autosomal allelic genes, $P G M^{1}$ and $P G M^{2}$ (frequencies $P G M^{1}=0.74, P G M^{2}=0.26$ ), with homozygotes $P G M^{1} / P G M^{1}$ and $P G M^{2} / P G M^{2}$, and heterozygotes $P G M^{1} / P G M^{2}$, representing electrophoretic types $I, 2$, and $2-I$, respectively.

On present evidence, the amount of PGM activity seems to be approximately equal in the three phenotypes so that gross deficiency is present in none of them.

The selective factors maintaining this polymorphism are quite unknown.

\section{IV: Acetylation Polymorphism}

A large variation in the metabolism of the antituberculous drug isoniazid was found to exist among humans by Bönicke and Reif (1953) and by Hughes (1953). Distribution histograms prepared by Biehl (1956, 1957) of the percentage of free urinary isoniazid showed a bimodal pattern. Mitchell, Riemensnider, Harsch, and Bell (1958) considered that the polymorphism for isoniazid might be genetically determined, and studies by Knight, Selin, and Harris (1959) and Evans, Manley, and McKusick (1960) showed that slow inactivation of isoniazid was 'recessive' to rapid inactivation and that the genes concerned were autosomal.

Further work by Sunahara (I96I), using a more refined microbiological technique, showed that the genotype could be directly determined, the homozygote 'rapids' inactivating distinctly more rapidly than the heterozygotes, so that the latter group formed an intermediate category. On this basis neither character is dominant to the other. Sunahara supports his hypothesis by studies on families.

Dufour, Knight, and Harris (1964) have studied the genetics of isoniazid metabolism in Caucasian, Negro, and Japanese populations, and calculated gene frequencies for each population. The gene frequency for the gene with 'rapid' effect is approximately 0.25 in both Negroes and Caucasians. In Japanese, on the other hand, the frequencies are reversed, 0.7I being the frequency for the 'rapid' effect gene. A study of Eskimos by Armstrong and Peart (1960) shows that these subjects are more frequently 'rapid' inactivators. Sunahara, Urano, and Ogawa (I96I) state that in Japan the more southerly the region, the higher the frequency of the slow allele, though this is not without exception.

Hughes, Biehl, Jones, and Schmidt (1954) and Hughes, Schmidt, and Biehl (1955) showed that there was a wide range of the percentages of a dose of isoniazid, which could be recovered from the urine as the actetylated derivative in different subjects. It was thought likely that the metabolic distinction between the phenotypes lay in their possession of different speeds of acetylation. Evans (1962) has produced evidence to support this hypothesis. Other drugs acetylated in the body, for example sulphadimidine, hydrallazine, and, in all probability, phenelzine (nardil), are dealt with in a 'polymorphic' fashion, whereas para-amino-salicylic acid and para-amino benzoic acid, which are also scetylated, are not dealt with polymorphically. Red cells contain only the latter acetylating enzyme, which is further evidence that two separate acetylating enzymes exist (Motulsky and Steinmann, 1962; Jenne, Macdonald, and Mendoza, I96r; Evans, 1965a). 
Side-effects from drugs used in clinical practice have been reported as being more frequent in slow than in rapid inactivators: this has been shown to apply in the case of the polyneuritis of isoniazidtreated tuberculous patients (Hughes et al., 1954; Devadatta, Gangadheram, Andrews, Fox, Ramakrishnan, Selkon, and Velu, 1960), and in patients with depression treated with phenelzine (Evans, Davison, and Pratt, 1965).

Although the side-effects are increased in slow inactivators of these drugs, there does not seem to be any reduction of the efficacy of the therapy in rapid inactivators, either of isoniazid in tuberculosis (Harris, I96I; Gow and Evans, 1964), or of phenelzine in depression (Evans et al., 1965). Perhaps the latter finding is not so surprising when one considers that an investigation by the Medical Research Council into the effects of mono-amine oxidase inhibitors in depression found that the drugs were no more effective than placebo (Brit. med. F., 1965).

There is evidence suggesting that the acetylation polymorphism exists in rabbits (Frymoyer and Jacox, 1963a, b), and in Cercopithecus aethiops (an African monkey) (Goedde, Schoepf, and Fleischmann, 1964).

The part played, if any, by these polymorphic enzymes in normal intermediary metabolism remains to be demonstrated. Such a demonstration might pave the way towards an understanding of the selective mechanisms involved in maintaining the polymorphism, which are at present quite unknown.

\section{V: Erythrocyte Acid Phosphatase}

Acid phosphatase is an enzyme which is widely distributed throughout the human body: it has the property of cleaving phosphoric monoesters at an optimal $p \mathrm{H}$ of 5 . A variety of different tissues contributes to the normal serum level of this enzyme. A raised serum acid phosphatase is most commonly associated with prostatic carcinoma, particularly if the total bulk of malignant tissue is 'great, as may happen if there are distant metastases.

That there are different structural forms of the acid phosphatase molecule is suggested by the fact that enzymes derived from different tissues have different inhibitors; certainly red cell and prostatic acid phosphatases have distinctly different properties in this respect.

A human polymorphism for red cell acid phosphatase was first described by Hopkinson, Spencer, and Harris (1963), and 5 different patterns (labelled A, BA, B, CA, CB) were detected when red cell acid phosphatase was studied using starch-gel electrophoresis. In a subsequent paper by the $\stackrel{\oplus}{+}$ same authors in 1964, their motives for selecting this particular enzyme for study are given. First, $\stackrel{S}{\rightarrow}$ that it was present in red cells and, therefore, $\frac{}{\circ}$ available (whereas parenchymal proteins require 음 biopsy or autopsy for their collection); and secondly, $\frac{\text { ? }}{\vec{\gamma}}$ because it was thought likely to be susceptible to $\AA$ examination by starch gel electrophoresis.

The fact that a protein, chosen at random (from the genetical standpoint), proves to be a striking example of genetical polymorphism may be fortui- $\vec{\omega}$ tous, or it may be regarded as providing support for the view that such molecular polymorphisms may be much commoner than is generally supposed.

Population and Family Studies. Population 을 studies are very incomplete as yet. Data from family studies are consistent with the suggestion of 3 Hopkinson et al. (1963) of three alleles $P^{A}, P^{B}$, and $P C$ at a single autosomal locus without dominance. There is a gene frequency of $0.36,0.60$, and $0.04, \overrightarrow{0}$ respectively, in an English population. Giblett. and Scott (1965) found slightly different figures in Seattle Caucasians $(0.394,0.547$, and 0.050$)$; their data for Seattle Negroes give frequencies of $0.226,0.759$, and 0.015 . $P C$ was zero for Seattle Orientals and Northern Japanese. In neither of $\frac{\varnothing}{\varnothing}$ the two studies has the phenotype CC been $\overrightarrow{\vec{F}}$ identified, but this is not surprising in view of the $\frac{9}{3}$ small number of individuals investigated to date and the expected rarity of this phenotype. Lai, Nevo, and Steinberg (1964) in Brazilian families of mixed ancestry (Caucasian, Negro, and South American Indian) have obtained frequencies of 0.20 , 0.77 , and 0.03 for $P^{A}, P^{B}$, and $P C$, respectively.

Enzyme Kinetics. Hopkinson and his coworkers (1964) have shown, using p-nitrophenyl 음 phosphate as substrate, that the activity of the acid phosphatase derived from the various phenotypes varies, with least activity in A, more in BA, $N$ more still in $B$ and $C A$, and greatest activity in CB (phenotype CC was not available). Their data support the hypothesis of a simple additive effect (e.g. the activity of BA is the mean of the activity of $B$ and A separately). They point out that if $a$ random sample of individuals were taken and red $\varnothing$ cell acid phosphatase activity estimated, the resulting conventional histogram-activity level on the abscissa; number of subjects at each activity level on the ordinate-would show a continuous unimodal distribution. In spite of this, the variation appears to be explicable on a simple three allele 
hypothesis. It seems possible that some examples of so-called quantitative multifactorial inheritance may have a similar uncomplicated underlying basis.

\section{VI: Serum Alkaline Phosphatase Polymorphism}

Alkaline phosphatase is a widely-distributed enzyme which has the property of cleaving many phosphoric monoesters, with an optimal $p \mathrm{H}$ of $9 \cdot 3$. Serum alkaline phosphatase is heterogeneous, consisting of components of bone, liver, and intestinal origin. Phosphatases derived from different tissues can be differentiated because they have differing sensitivities to a variety of chemical agents.

Two distinct situations need to be distinguished in discussing alkaline phosphatases: (a) the situation in pregnant women, and (b) the situation in non-pregnant human subjects. In both there is evidence of polymorphism; in both there is evidence of genetic control, but it is only in the former situation that genotypes can be deduced.

Pregnancy Enzymes. Boyer (196I) found that in the sera of all women in late pregnancy, extra alkaline phosphatase components could be distinguished by starch gel electrophoresis. Two bands, $A$ and $B$ (in his terminology), were distinguishable in Caucasians, either A or B, or both, being present. $A$ third pregnancy band was found only in Negroes. Complete agreement between bands in sera and placental extracts was found, except that examination of placental extracts showing both $A$ and $B$ zones revealed an intermediate zone $A B$, a distinction not possible with serum at that time.

Beckman, Björling, and Christodoulou (1966), using a modified technique described by Ashton and Braden (196I), have succeeded, in some cases, in distinguishing 3 zones in sera from subjects classified as $A B$. The distribution of the main types, $\mathrm{A}, \mathrm{AB}$, and $\mathrm{B}$, corresponds approximately to a Hardy-Weinberg distribution, but with deficiency of type $A B$ amounting to a loss of $15 \%$. Further data on this deficiency of $A B$ types will be awaited with interest, for it may represent an example of intrauterine selection against a heterozygote. Boyer (I96I) using presence or absence of the A band as the only safe classification (at that time) showed a significant variation in the presence of $\mathrm{A}$ between Nigerians (12\%) and Caucasians ( $54 \%$ ). In American Negroes (who are considered to be $70 \%$ African and 30\% Europeans in genetic origin) the expected frequency of the hypothetical ' $A$ ' allele as calculated from these data agreed with the observed value of 0.25 .

Beckman et al. (I966) also describe 4 further modified types, determined by electrophoresis of placental extracts.

The Situation Excluding Pregnancy. The significance of findings with regard to alkaline phosphatase polymorphism in non-pregnant, healthy human subjects has yet to be fully elucidated. Starch gel electrophoresis of sera from such subjects shows either one or two zones as a rule. Rarely a third band derived from bone is present. The first two zones mentioned have been described by Arfors, Beckman, and Lundin (1963) as zone A (possessors being phosphatase $(\mathrm{Pp}$ ) group $\mathrm{I}$ ), and zone $B$ (possessors of zones $A$ and $B$ being $P p ~ 2)$.

All of 89 monozygotic twin pairs were concordant for these groupings-6I pairs type I, 28 pairs type 2, strongly suggesting genetic control.

Further studies by Beckman (1964) in Brazil have shown that possession of zone $\mathbf{B}$ ( $\mathrm{Pp} 2$ status) has a positive correlation with positive $\mathrm{ABH}$ secretor status and Duffy blood group $\mathrm{Fy}^{\mathrm{a}}{ }^{+}$and negative correlation with Lewis $\left(a^{+} b^{-}\right)$and blood group $A_{1}$. This last-mentioned association has been confirmed in British subjects by Evans (1965b), and by Bamford, Harris, Luffman, Robson, and Cleghorn (1965) (who have also confirmed the Lewis association), and in America by Shreffler (I965). Shreffler, who has carried out semi-quantitative classification of phosphatase bands, points out that, on his data, not all blood group $A_{1}$ individuals show complete absence of zone $B$ protein, indicating that this association is not absolute. He also shows that secretor status (rather than Lewis grouping) is the primary factor (non-secretors of $\mathrm{ABH}$ substances being usually $\mathrm{Le}\left(\mathrm{a}^{+} \mathbf{b}^{-}\right)$) when analysis is made of the correlations mentioned above.

Thus, the appearance of this second alkaline phosphatase (i.e. zone B) is apparently determined by at least three loci. Its origin is considered to be the intestinal mucosa (Hodson, Latner, and Raine, 1962; Weiser, Bolt, and Pollard 1964). Zone A alkaline phosphatase originates in liver. It is certainly a remarkable thing that an enzyme of intestinal origin should in any way be controlled by loci associated with blood group substances for the interrelation is without rhyme or reason in our present state of knowledge.

From Beckman's data (1964) on family studies, it is evident that no simple explanation can be found that will enable genotypes to be deduced, using $\mathrm{PpI}$ and $\mathrm{Pp} 2$ as phenotypes. 


\section{VII: Erythrocyte Adenylate Kinase}

Adenylate kinase, also known as myokinase, is a phosphotransferase which has been principally studied in muscle, though it also occurs in other tissues, including red blood cells. It catalyses the following reaction: $2 \mathrm{ADP} \rightarrow \mathrm{ATP}+\mathrm{AMP}$.

Fildes and Harris (I966) report the examination of haemolysates of 960 unrelated English people for this enzyme, using starch gel electrophoresis. Three patterns emerge, designated AKI, AK2-I, and AK2. Family studies are consistent with a hypothesis of two autosomal alleles without dominance, so that, for the 3 phenotypes given above, there are three genotypes: $A K^{1} / A K^{1}, A K^{1} / A K^{2}$, and $A K^{2} / A K^{2}$, respectively. Only one example of the $\mathrm{AK}_{2}$ phenotype was found in 960 unrelated individuals mentioned (though three further examples were discovered during family studies). 95 individuals were $\mathrm{AK}$ 2-I, giving a gene frequency of 0.05 for $A K^{2}$ in English populations.

Disease associations have not yet been studied, nor is anything known of other selective forces which must be operating here.

\section{VIII: Serum Cholinesterase}

This enzyme is sometimes called pseudocholinesterase. Red cell cholinesterase (true cholinesterase) is a different enzyme having different properties. Cholinesterases catalyse the hydrolysis of choline esters, e.g. Acetyl choline $\rightarrow$ choline + acetic acid. Serum cholinesterase production appears to be under the control of at least two loci, $E_{1}$ and $E_{2}$. $E_{2}$ variants, though less well known than $E_{1}$ variants, will be discussed first because the percentage frequency of these is considerably higher than that of $E_{1}$ variants.

$E_{2}$ Variants: $C_{5}+$. Robson and Harris (1966) have recently produced further population and family studies on the serum phenotype $\mathrm{C}_{5}+$ which was reported in earlier papers by Harris, Hopkinson, and Robson (1962) and Harris, Hopkinson, Robson, and Whittaker (1963). The incidence of $\mathrm{C}_{5}+$ in the British sample of I94I persons is 0.097 . It is 0.29 in one of two Greek village populations studied.

Simpson (1966) reports that the frequency of the $\mathrm{C}_{5}+$ phenotype is about $7.9 \%$ in a Brazilian population, and gives details of serum cholinesterase activity (which is greater than normal in $\mathrm{C}_{5}+$ subjects) in subjects genotyped at both $E_{1}$ and $E_{2}$ loci.

It seems likely that most $\mathrm{C}_{5}+$ individuals are heterozygotes for a gene at a locus designated $E_{2}$; their genotype is, therefore, $E_{2}+E_{2}-$, where $\stackrel{\mathbb{D}}{\stackrel{D}{\overparen{D}}}$ $E_{2}-$ is the gene usually present at the $E_{2}$ locus:? and $E_{2}+$ the variant gene. The technique used $\overrightarrow{\vec{F}}$ (starch gel electrophoresis) does not distinguish the phenotype corresponding to the homozygote $E_{2}+\frac{\mathrm{C}}{\mathrm{O}}$ $E_{2}+$. The finding of $\mathrm{C}_{5}-$ parents with $\mathrm{C}_{5}+$ off- $\frac{\bar{y}}{\mathrm{w}}$ spring on several occasions does not agree with $\vec{\Phi}$ this hypothesis, but the authors suggest that 'a few of the heterozygotes may not be demonstrable byos the electrophoretic and staining methods at present $\overrightarrow{0}$ employed'.

$E_{1}$ Variants. Whereas subjects phenotyped as $\mathrm{C}_{5}+$ (corresponding to a variant at $E_{2}$ ) have increased serum cholinesterase, subjects who have atypical phenotypes with respect to the independent $\overrightarrow{t_{\vec{b}}}$ $E_{1}$ locus have diminished serum cholinesterase $e_{0}^{+}$ activity. Heterozygotes for an atypical gene $E_{1} a \supset$ are $E_{1}^{a} / E_{1}{ }^{u}$, where $E_{1}{ }^{u}$ is the usual gene; such subjects form $4 \%$ of a Toronto population and havew about $75 \%$ of normal serum cholinesterase activity. Subjects with both $E_{1}^{u}$ and $E_{2}+$ (usually $E_{1}{ }^{u} / E_{1}{ }^{a}, \vec{c}$ $\left.E_{2}+\mid E_{2}-\right)$ have serum cholinesterase activityo somewhat above normal. Among subjects with genotype $E_{1}{ }^{a} E_{1}{ }^{a}$ selected by the occurrence of prolonged apnoea from suxamethonium, no certain example of $\mathrm{C}_{5}+$ phenotype was detected (Robsono and Harris, I966). This suggests that the effect of $E_{2}+$ may afford protection against the sensitivity to suxamethonium brought about by $E_{1}{ }^{a} / E_{1}{ }^{a}$ geno $\overrightarrow{\overrightarrow{0}}$ type effect.

The atypical enzymes I (corresponding to $E_{1} u P_{P}$ $E_{1}^{a}$ ) and $\mathrm{A}$ (corresponding to $E_{1}{ }^{a} / E_{1}^{a}$ ) are known to. be inhibited to a lesser degree by dibucaine and the solanine alkaloids (found in potatoes) than is the usual enzyme $U$ (corresponding to $E_{1} u / E_{1}{ }^{u}$ ). This might mean that subjects possessing the $E_{1}{ }^{a}$ gene could resist solanine poisoning (an exceedingly rare condition at the present time, which produces diarrhoea and vomiting). Harris and Whittaker (I962) ccnclude that it is not clear how far the toxic effects of solanine can be attributed to the inhibitionof serum cholinesterase.

To know what advantage such a gene as $E_{1} \ddot{t}$ might confer, it would be useful to know if theres are any circumstances in which the variant cholines -0 terase might be directly advantageous. Naturall occurring dietary substrates are unlikely to passthe intestinal wall unchanged, but naturally occures ring inhibitors (which inhibit the atypical form less than the usual enzyme) can do so. The calabarbean ordeal used as a judicial procedure in certaing primitive tribes to separate the guilty (who die as a consequence of eserine poisoning) from the inno $-\frac{0}{-}$ cent (who do not) is an example of a selective force 
that should favour $E_{1}{ }^{a}$; but the geneticist would probably hesitate before accepting this as an example of pleiotrophy in which $E_{1}{ }^{a}$ effect determines both an atypical cholinesterase and moral rectitude. Naturally occurring inhibitors have been described in sugar-beet and oranges (Menn, McBain, and Dennis, 1964), and in apples (Orgell, I963).

\section{H: PLASMA PROTEIN POLYMORPHISMS}

The protein polymorphisms to be described are the following: (I) prealbumin, an $\alpha_{1}$ globulin; (2) Gc, an $\alpha_{2}$ globulin; (3) haptoglobin, an $\alpha_{2}$ globulin; (4) transferrin, a $\beta$ globulin; (5) lipoprotein systems, $\beta$ globulins; and (6) $\mathrm{Gm}+\mathrm{Inv}$ systems, $\gamma$ globulin.

The names given above (i.e. $\alpha_{1}, \alpha_{2}, \beta$, and $\gamma$ ) refer to the zones which the proteins occupy after serum is subjected to paper electrophoresis. Such a form of electrophoresis is altogether too crude to separate satisfactorily the components of the individual proteins listed above; methods commonly used for study of these proteins include agar gel and starch gel electrophoresis (which give much better resolution of the various components), and immunoelectrophoresis and gel diffusion precipitation. The serum protein enzyme polymorphisms and the blood group polymorphisms are not included here, being considered separately in view of their different properties and the differences in technique used in assessing them.

\section{I: Prealbumin}

Fagerhol and Braend (1965) report the results from 390 Norwegian blood donors of examination of the prealbumins, so-called because they migrate in front of the albumins in zone electrophoresis of serum in starch gel. Five types were distinguishable and designated MM, MS, SS, FM, FS. Only 16 donors were not $M M$, and of these, 9 were MS and 2 were SS. Studies on two families indicate that the prealbumins are inherited characteristics. The authors suggest a system of 3 codominant alleles $\operatorname{Pr}^{F}, \operatorname{Pr}^{M}, \operatorname{Pr}^{S}$. Using their data, the frequency of $\mathrm{Pr} S$ is about 0.02 . More studies will be needed before genetic drift can be excluded as being responsible for this situation.

\section{II: Gc: Group Specific Component}

Human $\alpha_{2}$ globulin is a complex mixture of proteins having similar electrophoretic mobilities. Haptoglobin, caeruloplasmin, and $\alpha_{2}$ macroglobulin are major components; among several minor components Hirschfeld (1959) was able to detect variation of mobility during immunoelectrophoretic analysis of human sera. To these $\alpha_{2}$ globulins he gave the name Group-specific component (Gc). Three immunoelectrophoretic patterns could be distinguished: a fast-moving pattern, Gc I-I; a slow-moving pattern, Gc 2-2; and an intermediate pattern, Gc 2-I which behaved in a manner similar to that of an admixture of approximately equal parts of Gc I-I and Gc 2-2.

Further study showed that the mode of inheritance for this system is that of a two-allele system without dominance. Genotypes $G c^{1} / G c^{1}, G c^{2} / G c^{1}$, and $G c^{2} / G c^{2}$ correspond to the phenotypes GcI-I, Gc2-I, and Gc2-2 (Hirschfeld, I960). No exceptions have been found to this rule, a fact that has contributed to the value of the system in investigating cases of disputed paternity (Reinskou, I966; Nerstrøm, 1963; Hirschfeld and Heiken, 1963).

Population studies have been carried out. Hirschfeld (1962) and Salzano and Shreffler (1966) give tables of data. Frequencies of the $G c^{2}$ gene vary from 0.025 in Navajo Indians and 0.01 in Australian aborigines to 0.67 in Xavante Indians of the Brazilian Mato Grosso studied by Neel, Salzano, Junqueira, Keiter, and Maybury-Lewis (1964). In Europeans, values for $G c^{2}$ are around 0.25 and in African Negroes somewhat below O.I. Kirk, Cleve, and Bearn (1963) give population studies for the $G_{C}$ genes from South East Asia and Australian aborigines. In 45 subjects from New Guinea there were five heterozygotes and two homozygotes for the variant allele $G c$ Aborigine, first described for aboriginal Australians. These data suggest that the variant gene has attained polymorphic status in this locality, and this may apply also in the New Hebrides (Kirk, 1965). A further variant, Gc Chippewa, has been described by Cleve, Kirk, Parker, Bearn, Schacht, Kleinman, and Horsfall (1963a) in Chippewa Indians, with 5 of 59 sera abnormal; other rarer variants have also been reported. The subject of Gc variant phenotypes has been discussed recently by Kitchin and Bearn (1966).

Chemical differences between GcI-I and Gc2-2 (Cleve, Prunier, and Bearn, 1963) appear to ke very slight and the structural differences responsible for the variation in electrophoretic mobility may well reside in a single amino acid substitution.

\section{III: Haptoglobin Polymorphism}

Between 1938 and 1940 Polanovski and Jayle described, in a series of papers, an $\alpha_{2}$ globulin in human serum, which had the unique property of binding haemoglobin. This was named hapto- 
globin, and in 1955 Smithies established (using starch gel technique) that haptoglobins were inherited as a two allele system, with no dominance.

Genetics. The two alleles determine 3 common phenotypes $\mathrm{Hp}$ I-I, Hp 2-I, and $\mathrm{Hp}$ 2-2, corresponding to the genotypes $H p^{1} / H p^{1}, H p^{1} / H p^{2}, H p^{2} /$ $H p^{2}$. Chemical reduction of purified haptoglobin followed by starch gel electrophoresis (using $8 \mathrm{M}$ urea and formic acid buffer) has enabled the Hp I-I phenotype to be separated further into three subphenotypes, $\mathrm{Hp}$ IF-IF, Hp IF-IS, Hp ISI $S$, these being determined by two alleles, $H_{p I} F$ and $H p \mathrm{I} S$, at the haptoglobin locus (Connell, Dixon, and Smithies, 1962).

Further analysis by Smithies, Connell, and Dixon (1962a, b) has shown that haptoglobin can be split into $\alpha$ and $\beta$ polypeptide chains; the genetic determinants of haptoglobin phenotype reside in the $\alpha$ chain. $\mathrm{Hp}^{2}$ units represent the fusion of two $\mathrm{Hp}^{1}$ units $\left(\alpha_{1}\right)$ into one molecule. Hp I-I consists of a single molecule with two $\alpha_{1}$ and one $\beta$ chain. Hp 2-2 consists of a series of polymers of structure $\left(\beta .2 \alpha_{1}\right)_{2 n+1}$ while $\mathrm{Hp} 2$-I consists of polymers which contain a unit of Hp I-I in combination with one of the $\mathrm{Hp} \mathrm{2-2}$ polymers. These $\mathrm{Hp}$ 2-I polymers, because of their different structure, behave quite differently from the $\mathrm{Hp} \mathrm{2-2}$ polymers on starch gel electrophoresis (see Allison, 1959; Javid, 1964; Smithies, 1964).

The additional discovery of two further relatively common phenotypes, Hp2-rM (Connell and Smithies, 1959; Giblett and Brooks, 1963) and Hp O (hereditary ahaptoglobinaemia), with 25 possible phenotype matings $\left[(3+2)^{2}\right]$, presents a formidable analytical problem.

Parker and Bearn (1963) have postulated control genes $C^{1}$ and $C^{2}$ for the two structural genes $H p^{1}$ and $H p^{2}$. These control genes may be active or passive (the latter being represented by $C^{1-}, C^{2-}$ ).

There are, thus, 8 possibilities: $C^{1} H p^{1}, C^{1} H p^{2}$, $C^{1-} H p^{1}, C^{1-} H p^{2}, C^{2} H p^{1}, C^{2} H p^{2}, C^{2-} H p^{1}, C^{2-} H p^{2}$ There are 36 genotypes $\left(\sum_{0}^{8} 8\right.$.) The basic tenet made in setting up the hypothesis is that the control element $C^{1}$ produces a substance with a higher affinity for $H p^{1}$ than $H p^{2}$. Thus, in genotypes where $H p^{2}$ is present without $C^{2}$, the structural gene $\left(H p^{2}\right)$ lacks controlling substances so that a modification, leading to phenotype $2-\mathrm{IM}$, is produced (unless both controlling genes are absent, in which case the phenotype is $\mathrm{HpO}$ ).

This hypothesis is an alternative to that of Giblett and Steinberg (1960), who have suggested a third allele $H p^{2 m}$ at the haptoglobin locus.
This hypothesis has been further debated by Sutton

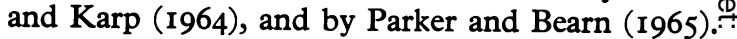

On neither hypothesis, as it stands, can a genetic $-\overrightarrow{\bar{c}}$ ally-based explanation be found for the presence of $\mathrm{HpO}$ in Australian and New Guinean populations $\frac{\mathrm{C}}{\mathrm{O}}$ in the virtual absence of $\mathrm{Hp} 2-\mathrm{IM}$ in these popula- $\overline{-}$. tions. Curtain, Gajdusek, Kidson, Gorman, Champ- $\bar{\varnothing}$ ness, and Rodrigue (1964) have found low serum haptoglobin levels in the lowlands of New Guineaes compared with the highlands, and a higher frequency $\vec{O}$ of $\mathrm{HpO}$ in the lowlands than in the highlands. $\overrightarrow{\vec{H}}$ They suggest that these findings may be due to $\omega$ removal of haptoglobin by increased vascular haemolysis, which is the commonest form of ac-0 quired ahaptoglobinaemia and which is related $\stackrel{+}{+}$ to the higher incidence of malaria in the lowland areas.

It is worth emphasizing that $\mathrm{HpO}$ (ahapto- 을 globinaemia) is the most difficult phenotype to be $\vec{z}$ sure of. There are a number of reports, including those of Galatius Jensen (1958) and Blumberg and $\stackrel{5}{5}$ Gentile (I96I), of individuals who are ahapto- $\vec{P}$ globinaemic at one time, but have detectable $\mathscr{O}$ haptoglobin at another. Severe liver disease may also distort phenotyping, as may infectious diseases other than malaria, and renal disease, etc. (see Shinton, Richardson, and Williams, 1965).

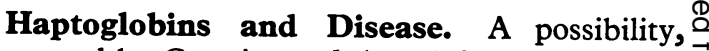
suggested by Curtain et al. (1964) from his data, is $\overrightarrow{\vec{O}}$ that there is a selective pressure favouring $\mathrm{Hp}^{1} 3$ in lowland areas for, 'since sera of type $I-I$ and type 2-I individuals appear to bind more haemoglobin per $100 \mathrm{ml}$ than does those of type 2-2, this could place the latter at a disadvantage in the maintenance of the delicate iron balance in the presence of haemolysis, intestinal iron loss due to parasitic infection and dietary iron deficiency'. However, it appears that the haptoglobin system in all its phenotypes is quite unable to cope with massive haemolysis; indeed, it can $\frac{7}{0}$ hardly bear the responsibility for the recovery of iron from defunct erythrocytes under normal of circumstances. However, a further report by $N$ Buettner-Janusch and Buettner-Janusch (1964) N showing a high HpI-I incidence in the coastal areas of Madagascar (which have a high malaria incidence) compared with that of the highlands (where malaria is much less common) suggests that the hypothesis that Curtain has put forward warrants further investigation. An association between the thalassaemia gene and $\mathrm{HpI}$ has been described in Greece (Blumberg, Murray, Allison, Barnicot, Hirschfeld, and Krimbas, 1964). Blackwell, Chen, Chen, and Uylangco (I964) 
have found the incidence of cholera unrelated to Hp phenotype among Fillipinos.

Population Studies. There are numerous population studies on haptoglobin frequency in different populations. Shim and Bearn (I964) summarize these (including data for $H_{p_{I} F}$ and $H p_{I} S$ ) up to mid-1964. Salzano and Sutton (1965) summarize data for the American continent and point out that the apparent cline of increasing gene frequency for $\mathrm{HpI}$ noted by Sutton, examining early data (up to 1960) from North to South in the American continent, has become blurred with further study, so that very large variations in gene frequency are found within small areas. It has been pointed out that clines are ultimately the product of two conflicting forces-selection (leading to unique local adaptation) and gene flow (leading to uniformity). Since cultural patterns evolve independently and population movements take place independently of these forces, clines are not likely to be found in human populations (Mayr, 1963).

$\mathrm{Hp}$ phenotyping has proved useful in the study of a hybrid population in Chile (Nagel and Soto, 1964) and in supporting the Indian origin of a group of Swedish gypsies (Beckman, Takman, and Arfors, 1965). Arends and Gallango (1965) have studied Guiana Indians, and give a table of South American data. The absence of Hp 2-IM is taken as indicating the absence of Negro admixture. $\mathrm{HpO}$ occurring in the same population suggests the acquired form of ahaptoglobinaemia, due to its commonest cause - malaria.

\section{IV: Transferrin Polymorphism}

Transferrin, a glycoprotein, is the serum protein to which iron is bound. It is a $\beta$-globulin with a molecular weight close to 90,000 and it is thought to contain a single polypeptide chain. The type most commonly found is designated $C$, and this, according to Jeppsson and Sjöquist (1963), is not one protein but two, the two fractions differing in their carbohydrate composition.

Seventeen variants have been described; 9 of these move more slowly on starch gel electrophoresis than Type $C$ and these are designated D group; 8 move more rapidly than $C$-the $B$ group. Each member of groups $B$ and $D$ is numbered or named. Data on the inheritance of these groups have not yet been established in all cases, but strong support is to be found for an autosomal allelic system without dominance, with alleles at a single locus. Beckman (1962) has reported an informative mating $\left(B_{2} D_{1} \times C C\right)$, from a Swedish population, two daughters being phenotyped as $\mathrm{B}_{2} \mathrm{C}$ and $\mathrm{CD}$, showing that three transferrin types are segregating in this family.

In only a few instances is the heterozygote frequency percentage of variant transferrins so high that maintenance by mutation is unlikely:

$\begin{array}{llr}\text { Navajo Indians } \mathrm{B}_{0-1}:- & 8 \% \\ \text { Caucasians } \mathrm{B}_{2} & :- & 1 \% \\ \text { Negroes } \mathrm{D}_{1} & :- & 12 \% \\ \text { Chinese } \mathrm{D}_{C h i} & :- & 6 \%\end{array}$

Kirk, Parker, and Bearn (1964) have reviewed data on $D_{1}$ and $D_{C h i}$ The $D_{1}$ variant is found both in African Negroes and in Aborigines (from Australia and Melanesia) who, on other evidence (blood group and serum protein gene frequencies) are of different genetic origin. Wang and Sutton (1965), using chymotrypsin digests, present evidence that $C$ and $D_{1}$ proteins differ consistently, in that a glycine residue on the $D_{1}$ polypeptide chain replaces an aspartic residue on the $C$ chain.

$\mathrm{D}_{C h i}$ is found in Malaya, Thailand, Formosa, North East India, and the Veddah of Ceylon. It has also been found in the Yupa Indians of Venezuela (Arends and Gallango, 1964) where it attains a high frequency: $\mathrm{C} / \mathrm{D}_{C h i}=4 \mathrm{I} \cdot 8 \%$; $\mathrm{D}_{C h i} / \mathrm{D}_{C h i}=16.4 \%$. Salzano and Sutton (1965) give a table of frequencies for the American continent. There is also a summary of data by Giblett (I962).

The Navajo, Caucasian, Negro, and Chinese populations may represent states of balanced polymorphism. So far, studies have shown no significant difference in the rate of disappearance of iron from the serum containing the variant proteins. One function possessed by transferrin by virtue of its iron-binding function is as an antibacterial agent, its mode of action depending on the unavailability of iron to enable bacteria to grow. This effect, it has been claimed, might convey differing antibacterial resistance to possessors of variant proteins, but as the capacity of these proteins for binding iron appears to be normal, it is difficult to see how this can work.

Ashton (1965) has studied the polymorphism of serum transferrins in cattle. He gives data showing that the reproductive performance of cattle is influenced by several effects of the serum transferrin locus: (a) advantage in utero; (b) maternal-foetal incompatibility; and (c) fertility which differs between phenotypes in both cows and bulls. Ashton has constructed a model for these effects, which shows a comparison between expected and observed breeding efficiencies with analysis for each of the effects.

The estimated population excess of heterozygotes 
is very close to that observed. It will be of great interest to see whether a similar model can be constructed for the human polymorphisms which exist for the transferrin proteins.

\section{V: Lipoprotein Polymorphisms}

The Ag System. Allison and Blumberg (I96I) found that serum from a patient (C de B) who had received multiple transfusions gave welldefined precipitation reactions in agar with some, but not all, sera from other individuals. The antigen in these sera was shown by family studies to be inherited independently of other systems such as haptoglobin, transferrin, and $\gamma$-globulin types. Possessors of it were designated $\mathrm{Ag}(\mathrm{a}+)$; non-possessors $\mathbf{A g}(\mathrm{a}-)$. $\mathbf{A g}(\mathrm{a}-)$ subjects were shown to be homozygous for a recessive gene $A g: A g(+)$ subjects homozygous or heterozygous for the allelic gene designated $A g^{A}$ (Allison and Blumberg, I96I; Blumberg and Allison, 196I; Blumberg, Bernanke, and Allison, 1962).

The antigen has been identified as a low density protein which migrates as an $\alpha_{2}$ globulin in agar gel electrophoresis but as a $\beta$ globulin on paper electrophoresis. Further studies have shown that it is a $\beta$-lipoprotein (Blumberg, Dray, and Robinson (I962), and it seems possible that a carbohydrate component (which all lipoproteins contain) contributes to its antigenicity.

The subject has become complicated by the fact that various antibody-containing sera studied (of which serum C de B was the first) contain antibodies to more than one antigen (such antibodies are not found at all until more than 20 transfusions have been given (Blumberg et al., 1964)). Serum C de B contains at least three antibodies (reacting with 3 distinct antigens) so that, though the classification of subjects as of phenotype $\mathrm{Ag}(\mathrm{a}-)$ remains satisfactory, it now indicates that they are homozygous for the absence of at least three genetic factors (determining specificities $a_{1}, x$, and $z$ ). Hirschfeld (1964) has reviewed this complex subject.

It should be clear from the foregoing that population studies are not meaningful if the phenotypes are simply designated $\mathbf{A g}(\mathrm{a}+)$ and $\mathrm{Ag}(-)$, for $\mathbf{A g}(\mathrm{a}+)$ can indicate $\mathbf{A g}\left(a_{1}+; \mathbf{x}-, z_{-}\right)$or $\mathbf{A g}$ $\left(a_{1}+; x+; z-\right)$ etc. Allison and Blumberg (1965) have tabulated the population study data.

No differences have been found in total cholesterol, total phospholipid, or cholesterol/phospholipid ratio, between $\mathrm{Ag}(\mathrm{a}+)$ and $\mathbf{A g}(-)$ subjects (Blumberg et al., I962); furthermore, no differences have been found in the incidence of rheumatic fever or coronary artery disease between $\Phi$ the two groups. No consistent differences have $\stackrel{\mathbb{P}}{\rightarrow}$ been found in diabetics for, though Blumberg, $\vec{\Rightarrow}$ Ledbetter, and Visnich (Alison and Blumberg, 1965) found a higher proportion of $\mathrm{Ag}(\mathrm{a}+)_{\mathrm{C}} \mathrm{C}$ subjects (than expected) in a group of diabetic $\frac{\overline{\bar{O}}}{\overline{0}}$. American Negroes, this was not the case in a $\frac{\bar{\sigma}}{\bar{\sigma}}$ Norwegian and Brazilian population studied by气 Berg, Blumberg, and Leon (quoted by Alison and ${ }_{\infty}^{\cong}$ Blumberg). The selective factors maintaining the $\vec{\circ}$ polymorphism thus remain to be established.

The Lp and Ld Systems. Further lipoprotein polymorphisms have been described by Berḡ̋ (1963) (the Lp system) and Berg (1965) (the Ld system). Gedde-Dahl and Berg (1965) give-further data on the first of these systems.

\section{VI: Gm and Inv Systems}

Sera from children who have received multiple⿳亠丷厂犬 transfusions have also been shown to contain agglutinating antibodies against $\gamma$-globulin absent $\mathscr{Я}$ from their own $\gamma$-globulin (Allen and Kunkel,. $v$ I963a, b). The antigens responsible for this effect? are due to genetically determined factors-these genes being present as multiple alleles at a genetic locus $(\mathrm{Gm})$ or at several closely linked loci.

If $O$ positive $D D$ (Rhesus) cells are (i) coated $\stackrel{\circ}{\stackrel{\Phi}{\circ}}$ with incomplete anti-D antibody containing $\mathrm{Gm}(\mathrm{a}), \underset{\overrightarrow{\mathrm{F}}}{\overrightarrow{\mathrm{C}}}$ these cells can be (ii) agglutinated by the serum of $\frac{1}{3}$

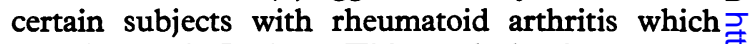
contains anti $\mathrm{Gm}(\mathrm{a})$. This agglutination can be? (iii) inhibited by $\gamma$ globulin from possessors of Gm(a) (Grubb and Laurell, I956).

Thus, a system showing this reaction must $\frac{0}{3}$ contain:- (i) an appropriate coating or sensitizing. serum; (ii) an appropriate agglutinating serum; and (iii) an appropriate inhibiting serum.

Further $\mathrm{Gm}$ factors (factors in category (iii)) $\frac{\text { 의 }}{2}$ have been detected by finding agglutinating sera which have reacted with some, but not all, of inhibiting serum known to show the $\mathrm{Gm}$ (a) factor N (or other known $\mathrm{Gm}$ factors). Examples of this ${ }_{\mathrm{N}}$ are $\mathrm{Gm}(\mathrm{b})$ (Harboe, I959); $\mathrm{Gm}(\mathrm{X})$ (Harboe and Lundevall, I959); Gm(r) (Fudenberg, I96I); Gmlike (Steinberg, Giles, and Stauffer, I960); Gm(D) (Thomas and Kampf, 196I); and Gm(e) (Ropartz, Rivat, and Rousseau 1962). All Gm factors have in common the property of being $\gamma \mathrm{G}$-globulins ${ }_{+}^{+}$ (otherwise $7 \mathrm{~S} \gamma$-globulins), and differences between ${ }_{0}^{\circ}$ them are determined by differences in the heavy $\vec{\Phi}$ (H) polypeptide chains of the $\gamma$-globulin molecule. $\frac{?}{\mathbb{D}}$

A second group of factors, independent of $\mathrm{Gm}$, $\stackrel{\Omega}{\circ}$ associated with all three main classes of proteins 
possessing antibody activity $(\gamma \mathrm{G}, \gamma \mathrm{M}$, and $\gamma \mathrm{A})$, and determined by light polypeptide chain ( $\mathrm{L}$ chain) differences in the $\gamma$-globulin, has been described: this is the Inv system. Descriptions include those of $\operatorname{Inv}(a)$ (Ropartz, Lenoir, and Rivat, I96I); Inv(b) (Steinberg, Wilson, and Lanset, 1962); and Inv(1) (Ropartz et al., I962). The genetics of the Inv locus have been discussed by Ropartz (1963).

The subject of $\mathrm{Gm}$ systems has become very complex, particularly in considering Negro and Mongoloid populations, and diversity of nomenclature has not made understanding of these complexities any easier. No genetic hypothesis seems to exist, which will explain all the rare phenotypes encountered. In Caucasians $\mathrm{Gm}$ (a) and Gm (b) appear to behave as the products of different alleles. This is not true in Negroes, for $95 \%$ of American Negroes are $\mathrm{Gm}(\mathrm{a}+\mathrm{b}+)$. With mating of 2 subjects of genotype $\mathrm{Gm}^{a} / \mathrm{Gm}^{b}$, only $50 \%$ of offspring will be $\mathrm{Gm}(\mathrm{a}+\mathrm{b}+)$, and, as Steinberg et al. (I960) have pointed out, $50 \%$ of conceptions would have to end in death to maintain heterozygosityan untenable hypothesis. Therefore, a further allele $G m^{a b}$ has to be postulated. Gmar, $G m^{a x}$, $G m^{a r x}$, and $G m^{a b c}$ have also been described. Further data on this subject (which seems likely to become a great deal more complex or a great deal simpler if some current ideas prove ultimately untenable) can be found in Deicher, Wendt, Theile, and Kirchberg (1963), Ropartz, Rivat, Rousseau, Baitsch, and Van Loghem (1963), and Steinberg and Goldblum (1965).

Attempts to relate variations in the frequencies of inherited $\gamma$-globulin groups to certain pathological conditions have not, as yet, proved successful.

Data on population studies are to be found in papers by Ropartz et al. (1963), Steinberg (1962), and Steinberg and Goldblum (1965).

\section{SUMMARY}

Morton, Krieger, and Mi (1966) discuss several aspects of polymorphism and give a list of methods (and the errors thereof) used to study the selective forces involved in maintaining polymorphisms.

(I) Identification of the relevant environmental differences between populations with high and low gene frequencies.

(2) Detection of systematic departures of genotype frequencies from Hardy-Weinberg equilibrium.

(3) Association between genotype and a specific type of morbidity or response to a specific agent.
(4) Analysis of adaptive trends in genotype frequency with age or among successive generations.

(5) Detection of different genotype frequencies in two sexes.

(6) Measurement of fertility and mortality differentials among genotypes.

(7) Analysis of departures from Mendelian segregation frequencies.

Examples of the use of these various methods are included under the individual polymorphisms which have been described above.

The subject of human polymorphism may confidently be expected to proliferate over the next few years. It is to be hoped that attention will continue to be paid to the part played by polymorphic situations in human disease, and that the search for further polymorphic systems will be related to the need to find an explanation for those diseases in which inheritance plays an important aetiological role.

I wish to acknowledge my indebtedness to Dr. D. A. Price-Evans for assistance with the biochemical sections of this paper and to Dr. D. J. Weatherall for help with the section on the haemoglobinopathies. The paper was read and criticized by Professor and Mrs C. A. Clarke and by Dr. R. B. McConnell, and I am most grateful to them for their advice. I also wish to thank Mrs. K. M. Cogley for secretarial assistance.

\section{REFERENCES}

Aird I., Bentall, H. H., and Fraser Roberts, J. A. (1953). A relationship between cancer of stomach and the ABO blood groups. Brit. med. F., I, 799.

Åkesson, H. O. (1959). Taste sensitivity to phenyl-thio-urea in tuberculosis and diabetes mellitus. Ann. hum. Genet., 23, 262.

Allen, J. C., and Kunkel, H. G. (I963a). Antibodies to genetic types of gamma globulin after multiple transfusions. Science, 139, 418. -, and - (1963b). Characteristics of the antibodies against gamma globulin in patients with multiple transfusions. $\mathcal{f}$. clin. Invest., 42, 913.

Allison, A. C. (1954). The distribution of the sickle-cell trait in East Africa and elsewhere, and its apparent relationship to the incidence of subtertian malaria. Trans. roy. Soc. trop. Med. Hyg., 48,312 .

(1957). Malaria in carriers of the sickle-cell trait and in newborn children. Exp. Parasit., 6, 418.

- (1959). Genetic control of human haptoglobin synthesis. Nature (Lond.), $183,1312$.

- (1963). Malaria and glucose-6-phosphate dehydrogenase deficiency. ibid., 197, 609 .

- (1965). Population genetics of abnormal haemoglobins and glucose-6-phosphate dehydrogenase deficiency In Abnormal Haemoglobins in Africa, ed. J. H. P. Jonxis, p. 365. Blackwell Scientific Publications, Oxford.

-, and Blumberg B. S. (196I). An isoprecipitation reaction distinguishing human serum-protein types. Lancet, I, 634. , and - (1965). Serum lipoprotein allotypes in man. Progr. med. Ginet., 4, 176.

Anderson, M., Went, L. N., MacIver, J. E., and Dixon, H. G. (1960). Sickle-cell disease in pregnancy. Lancet, 2, 516.

Arends, T., and Gallango, M. L. (1964). Transferrins in Venezuelan Indians: high frequency of a slow-moving variant. Science, 143, 367 
- , and - (1965). Haemoglobin types and blood serum factors in British Guiana Indians. Brit. F. Haemat., 11, 350.

Arfors, K. E., Beckman, L., and Lundin, L. G. (1963). Genetic variations of human serum phosphatases. Acta genet. (Basel), 13, 89.

Armstrong, A. R., and Peart, H. E. (1960). A comparison between the behavior of Eskimos and non-Eskimos to the administration of isoniazid. Amer. Rev. resp. Dis., 81, 588

Armstrong, M. D., Yates, K., Kakimoto, Y., Taniguchi, K., and Kappe, T. (1963). Excretion of $\beta$-aminoisobutyric acid by man. f. biol. Chem., 238, 1447.

Ashton, G. C. (1965). Cattle serum transferrins. A balanced polymorphism? Genetics, 52, 983.

- , and Braden, A. W. H. (1961). Serum $\beta$-globulin polymorphism in mice. Aust. F. biol. Sci., 14, 248.

Azevêdo, E., Krieger, H., Mi, M. P., and Morton, N. E. (I965). P.T.C. taste sensitivity and endemic goiter in Brazil. Amer. f. hum. Genet., 17, 87.

Bamford, K. F., Harris, H., Luffman, J. E., Robson, E. B., and Cleghorn, T. E. (1965). Serum-alkaline-phosphatase and the ABO blood groups. Lancet 1,530 .

Bannerman, R. M. (1962). Selection in thalassaemia. In Haemoglobin-Colloquium, ed. H. Lehmann and K. Betke, p. 93. Thieme, Stuttgart.

Barnicot, N. A. (1950). Taste deficiency for phenylthiourea in African Negroes and Chinese. Ann. Eugen. (Lond.), 15, 248.

_-, Allison, A. C., Blumberg, B. S., Deliyannis, G., Krimbas, C., and Ballas, A. (1963). Haemoglobin types in Greek populations. Ann. hum. Genet., 26, 229.

Beckman, L. (1962). Slow and fast transferrin variants in the same pedigree. Nature (Lond.), 194, 796.

- (1964). Associations between human serum alkaline phosphatases and blood groups. Acta genet. (Basel), 14, 286.

-, Björling, G., and Christodoulou, C. (1966). Pregnancy enzymes and placental polymorphism. I. Alkaline phosphatase. ibid., 16, 59 .

-, Takman, J., and Arfors, K. E. (1965). Distributions of blood and serum groups in a Swedish Gypsy population. ibid., 15, 134 .

Berg, K. (1963). A new serum type in man-the Lp system. Acta path. microbiol. scand., 59, 369 .

(1965). A new serum type in man-the Ld system. Vox Sang. (Basel), 10, 513 .

-, Blumberg, and Leon (quoted by Allison and Blumberg, I965).

Biehl, J. P. (1956). The role of the dose and the metabolic fate of ioniazid in the emergence of isoniazid resistance. Trans. Conf. Chemother. Tuberc. 15, 279.

- (1957). Emergence of drug resistance as related to the dosage and metabolism of isoniazid. ibid., 16, 108.

Blackwell, R. Q., Chen, H. H., Chen, H. C., and Uylangco, C. V. (1964). Haptoglobin distribution in a Filipino population. Nature (Lond.), 202, 814.

Blumberg, B. S., and Allison, A. C. (1961). Study on the isoprecipitin determined human serum polymorphism. Proc. 2nd int. Congr. Hum. Genet. Rome, 2, 733.

-, Bernanke, D., and Allison, A. C. (1962). A human lipoprotein polymorphism. F. clin. Invest., 41, 1936.

-, Dray, S., and Robinson, J. C. (1962). Antigen polymorphism of a low-density beta-lipoprotein. Allotypy in human serum. Nature (Lond.), 194, 656

, and Gentile, $Z$. (1961). Haptoglobins and transferrins of two tropical populations. ibid., 189, 897.

, Ledbetter, and Visnich (quoted by Allison and Blumberg, 1965).

-, Murray, R. F., Allison, A. C., Barnicot, N. A., Hirschfeld, J., and Krimbas, C. (1964). Serum protein polymorphisms in Greek populations. Ann. hum. Genet., 28, 189.

Bönicke, R., and Reif, W. (1953). Enzymatische Inaktivierung von Isonicotinsäure-hydrazid in menschlichen und tierischen Organismus. Naunyn-Schmiedeberg's Arch. exp. Path. Pharmak., 220, $32 \mathrm{r}$.

Boyer, S. H. (1961). Alkaline phosphatase in human sera and placentae. Science, 134, 1002.

Brand, N. (1963). Taste sensitivity and endemic goitre in Israel. Ann. hum. Genet., 26, 321 .

(1964). Taste response and poliomyelitis. ibid., 27, 233.
Brit. med. F. (1965). Clinical trial of the treatment of depressive illness. Report to the Medical Research Council by its Clinical Psychiatry Committee. 1, 88 I.

Brues, A. M. (1954). Selection and polymorphism in the A-B-O blood groups. Amer. F. phys. Anthrop., 12, 559.

Buettner-Janusch, J., and Buettner-Janusch, V. (1964). Hemo globins, haptoglobins and transferrins in the peoples of Mada-C gascar. ibid., 22, 163 .

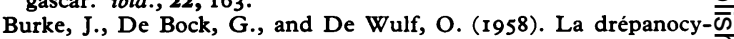
traemie simple et l'anaemia drépanocytaire au Kwango (Congo Belge). Mém. Acad. roy. Sci. colon. Cl. Sci. nat. méd., 7, 1 .

Cabannes, R. (1965). Répartition des hemoglobines anormales 0 dans la partie ouest du continent africain (with English Summary). ${ }^{\text {s }}$ In Abnormal Haemoglobins in Africa, ed. J. H. P. Jonxis, p. $291 . \vec{\circ}$ Blackwell Scientific Publications, Oxford.

Carcassi, U., Ceppellini, R., and Pitzus, F. (1957). Frequenza della $\vec{\longrightarrow}$ talassemia in quattro popolazioni sarde e suoi rapporti con la $\mathrm{O}^{\omega}$ distribuzione dei gruppi sanguini e della malaria. Boll. Ist sierotexmilan., 36, 206.

Choremis, C., Fessas, Ph., Kattamis, C., Stomatoyannopoulos, G.,. Zannos-Mariolea, L., Karaklis, A., and Belios, G. (1963). Three. ${ }^{A}$ inherited red-cell abnormalities in a district of Greece. Thalas-.saemia, sickling, and glucose-6-phosphate dehydrogenase de- $\vec{A}$ ficiency. Lancet, $\mathbf{r}, 907$.

Chung, C. S., Matsunaga, E., and Morton, N. E. (1961). The 윽 MN polymorphism in Japan. fap. F. hum. Genet., 6, I.

- and Morton, N. E. (1961). Selection at the ABO locus. Amer. F. hum. Genet., 13, 9.

Ciba Foundation (1965). Symposium on ColourVision, ed. A. V. S. Reuck and J. Knight. Churchill, London.

Clarke, C. A. (1964). Genetics for the Clinician, 2nd ed., p. 76. $\vec{c}$ Blackwell Scientific Publications, Oxford.

Clements, F. W. (1960). Naturally occurring goitrogens. Brit. med.) Bull., 16, 133 .

Cleve, H., Kirk, R. L., Parker, W. C., Bearn, A. G., Schacht, L. E., Kleinman, H., and Horsfall, W. R. (1963a). Two genetic variants of the group-specific component of human sera-Gc Chippewa and Gc Aborigine. Amer. F. hum. Genet., 15, 368.

- Prunier, J. H., and Bearn, A. G. (I963b). Isolation and partialo characterization of the two principal inherited group-specific $\mathbb{D}$ components of human serum. F. exp. Med., 118, 71 I .

Connell, G. E., Dixon, G. H., and Smithies, O. (1962). Subdivision $\overline{\bar{O}}$ of the three common haptoglobin types based on 'hidden' dif- 3 ferences. Nature (Lond.), 193, 505.

, and Smithies, O. (1959). Human haptoglobins: estimation and purification. Biochem. F., 72, 115.

Covarrubias, E., Barzelatto, J., Stevenson, C., Bobadilla, E., Pardo, A., and Beckers, C. (1965). Taste sensitivity to phenyl-thiocarbamide and endemic goitre among Pewenche Indians. ibid., 205, 1036.

Curtain, C. C., Gajdusek, D. C., Kidson, C., Gorman, J., Champ ness, L., and Rodrigue, R. (1964) (quoted by Kirk, 1965).

Das, S. R., and Mukherjee, D. P. (1964). P.T.C. taste sensitivity survey among the Pareng Gadaba, the Ollaro Gadaba and the Konda Paroja of Koraput District, Orissa. Acta genet. (Basel), 음 14, 168 .

-, and Bhattachariee, P. N. (1963). P.T.C. taste threshold distribution in the Bado Gadaba and the Bareng Paroja of Koraput District in Orissa. ibid., 13, 369 .

Davidson, R. G., Childs, B., and Siniscalco, M. (1964). Genetic $O \widetilde{O}$ variations in the quantitative control of erythrocyte glucose-6phosphate dehydrogenase activity. Ann. hum. Genet., 28, 61.

Deicher, H., Wendt, G. G., Theile, U., and Kirchberg, G. (1963). N

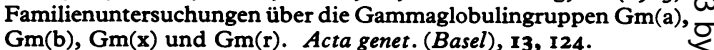

Delbrouck, J. (1958). Contribution à la génétique de la sicklémie.co Maintien de la fréquence évelée de sicklémie au Congo belge. Ann. Soc. belge Méd. trop., 38, 103.

Dern, R. J., Brewer, G. J., Tashian, R. E., and Shows, T. B. (1966). Hereditary variation of erythrocytic 6-phosphogluconate dehydro- $T$ genase. f. Lab. clin. Med., 67, 255.

Devadatta, S., Gangadheram, P. R. J., Andrews, R. H., Fox, W., Ramakrishnan, C. V., Selkon, J. B., and Velu, S. (1960). Peri- $\stackrel{\longrightarrow}{\square}$ pheral neuritis due to isoniazid. Bull. Wld Hlth Org., 23, 587.

Dreyer, V., and Goldschmidt, E. (1965). The offspring of two colour-blind parents. Acta genet. (Basel), 15, 97. 
Dufour, A. P., Knight, R. A., and Harris, H. W. (1964). Genetic of isoniazid metabolism in Caucasian, Negro, and Japanese populations. Science, 145, 391 .

Dutta, P. C. (1966). A review of the inherited defective colourvision variability and selection relaxation among the Indians. Acta Genet. (Basel), 16, 327

Edington, G. M., and Laing, W. N. (1957). Relationship between haemoglobins $\mathrm{C}$ and $\mathrm{S}$ and malaria in Ghana. Brit. med. f., 2, 143.

-, and Lehmann, H. (1956). The distribution of Haemoglobin C in West Africa. Man, 56, 34 .

Edwards, J. H. (1965). The meaning of the associations between blood groups and disease. Ann. hum. Genet., 29, 77.

Eichner, E. R., Finn, R., and Krevans, J. R. (1963). Relationship between serum antibody-levels and the ABO blood group polymorphism. Nature (Lond.), 198, I64.

Evans, D. A. P. (1962). Pharmacogénétique. Méd. et Hyg. (Genève), 20, 905 .

(1963). Pharmacogenetics. Amer. F. Med., 34, 639.

(1965a). Conjoint clinic on drugs and genes. f. chron. Dis., $18,59$.

(1965b). Confirmation of association between ABO blood groups and salivary $\mathrm{ABH}$ secretor phenotypes and electrophoretic patterns of serum alkaline phosphatase. f. med. Genet., 2, 126.

- Davison, K., and Pratt, R. T. C. (1965). The influence of acetylator phenotype on the effects of treating depression with phenelzine. Clin. Pharmacol. Ther., 6, 430.

-, Manley, K. A., and McKusick, V. A. (1960). Genetic control of isoniazid metabolism in man. Brit. med.. ., $2,485$.

Fagerhol, M. K., and Braend, M. (1965). Serum prealbumin: polymorphism in man. Science, $\mathbf{1 4 9}, 986$.

Fildes, R. A., and Harris, H. (I966). Genetically determined variation of adenylate kinase in man. Nature (Lond.), 209, 261.

- , and Parr, C. W. (1963). Human red cell phosphogluconate dehydrogenases. ibid., 200,890 .

- , and - (1964). Various forms of human erythrocyte phosphogluconate dehydrogenase. Proc. 6th int. Congr. Biochem., New York, p. 229.

Firschein, I. L. (I96I). Population dynamics of the sickle-cell trait in the Black Caribs of British Honduras, Central America. Amer. F. hum. Genet., 13, 233.

Fischer, R., and Griffin, F. (1960). Factors involved in the mechanism of 'taste-blindness'. $\mathcal{F}$. Hered., $51,182$.

-_, - England, S., and Garn, S. M. (196I). Taste threshold and food dislikes. Nature (Lond.), 191, 1328.

- - - and Pasmanick, B. (1963). The perception of taste: some psychophysiological, pathophysiological, pharmacological and clinical asperts. Proc. Amer. psychopath. Ass., 53, 129.

Fisher, R. A., Ford, E. B., and Huxley, J. S. (1939). Taste-testing the anthropoid apes. Nature (Lond.), 144, 750 .

Flatz, G., Pik, C., and Sringam, S. (1965a). Haemoglobin E and $\beta-$ thalassaemia: their distribution in Thailand. Ann. hum. Genet., 29, 151 .

- - and - (1965b). Haemoglobinopathies in Thailand. I. A study of patients with the thalassaemia syndrome and their families. Brit. F. Haemat., $11,216$.

Ford, E. B. (1940). The New Systematics, ed. Julian Huxley, p. 493. Clarendon Press, Oxford.

- (1965). Genetic Polymorphism. Faber and Faber, London.

Fraser, G. R. (1961). Cretinism and taste sensitivity to phenylthiocarbamide. Lancet, $1,964$.

- (1963). A genetical study of goitre. Ann. hum. Genet., 26, 335 .

, Stamatoyannopoulos, G., Kattamis, C., Loukopoulos, D., Defaranas, B., Kitsos, C., Zannos-Mariolea, L., Choremis, C., Fessas, P., and Motulsky, A. G. (1964). Thalassaemias, abnormal hemoglobins and Glucose-6-phosphate dehydrogenase deficiency in the Arta area of Greece: diagnostic and genetic aspects of complete village studies. Ann. N.Y. Acad. Sci., 119, 415.

Frymoyer, J. W., and Jacox, R. F. (1963a). Investigation of the genetic control of sulphadiazine and isoniazid metabolism in the rabbit. F. Lab. clin. Med., 62, 891 .

, and - (1963b). Studies of genetically controlled sulphadiazine acetylation in rabbit livers: possible identification of the heterozygous trait. ibid., 62, 905.

Fudenberg, H. (1961). Quoted in Brandtzaeg, B., Fudenberg, H., and Mohr, J. The $\mathrm{Gm}(\mathrm{r})$ serum group. Acta genet. (Basel), II, I 70.
Fullerton, W. T., Hendrickse, J. P. de V., and Watson Williams, E. J. (1965). Haemoglobin SC disease in pregancy. In Abnormal Haemoglobins in Africa, ed. J. H. P. Jonxis, p. 4II. Blackwell Scientific Publications, Oxford.

Galatius-Jensen, F. (1958). Rare phenotypes in the Hp system. Acta genet. (Basel), 8, 248.

Gartler, S. M. (I96I). Comments on the population dynamics of $\beta$-aminoisobutyric aciduria. In Proceedings of the Conference on Genetic Polymorphisms and Geographic Variations in Disease, ed. B. S. Blumberg, p. 192. Grune and Stratton, New York.

Gedde-Dahl, T., Jr., and Berg, K. (1965). Linkage in man: the Inv and the Lp serum type systems. Nature (Lond.), 208, I 126.

Giblett, E. R. (1962). The plasma transferrins. Progr. med. Genet. (N.Y.), 2, 34 .

-, and Brooks, L. E. (1963). Haptoglobin types. Haptoglobin sub-types in three racial groups. Nature (Lond.), 197, 576.

- and Scott, N. M. (1965). Red cell acid phosphatase: racial distribution and report of a new phenotype. Amer. F. hum. Genet. 17,425 .

- and Steinberg, A. G. (1960). The inheritance of serum haptoglobin types in American Negroes: evidence for a third allele $\mathrm{Hp}^{2 \mathrm{~m}}$. ibid., 12, 160 .

Goedde, H. W., Schoepf, E., and Fleischmann, D. (1964). Studies on pharmacogenetics. I. The enzymic acetylation of isonicotic acid hydrazide (INH). Biochem. Pharmacol., 13, 1671.

Gow, J. G., and Evans, D. A. P. (1964). A study of the influence of the isoniazid inactivator phenotype on reversion in genitourinary tuberculosis. Tubercle (Edinb.), 45, 136.

Gramberg-Danielson, B. (196I). Untersuchungen über die Unfallhaufigheit von Farbenuntüchtigen im Strassenverkehr. Klin. Mbl. Augenheilk., 139, 677 .

Griffin, F., and Fischer, R. (1960). Differential reactivity of saliva from 'tasters' and 'non-tasters' of 6-N-propylthiouracil. Nature (Lond.), 187, 417 .

Grubb, R., and Laurell, A. B. (1956). Hereditary serological human serum groups. Acta path. microbiol. scand., 39, 390.

Haldane, J. B. S. (1949). Disease and evolution. Ricerca sci., 19, (Suppl.), 68.

Harboe, M. (1959). A new hemagglutinating substance in the $\mathrm{Gm}$ system, anti-Gm ${ }^{\mathrm{b}}$. Acta path. microbiol. scand., 47, $19 \mathrm{I}$.

, and Lundevall, J. (1959). A new type in the Gm system. ibid., 45, 357 .

Harris, H., Hopkinson, D. A., and Robson, E. B. (1962). Twodimensional electrophoresis of pseudocholinesterase components in normal human serum. Nature (Lond.), 196, 1296.

,,--- , and Whittaker, M. (1963). Genetical studies on a new variant of serum cholinesterase detected by electrophoresis. Ann. hum. Genet., 26, 359.

, Kalmus, H., and Trotter, W. R. (1949). Taste sensitivity to phenylthiourea in goitre and diabetes. Lancet, $2,1038$.

, and Whittaker, M. (1962). The serum cholineterase variants. A study of 22 families selected via the 'intermediate' phenotype. Ann. hum. Genet., 26, 59.

Harris, H. W. (196I). High-dose isoniazid compared with standarddose isoniazid with PAS, in the treatment of previously untreated cavitary pulmonary tuberculosis. Trans. Res. Conf. Pulm. Dis., 39.

Harris, R. (1963). Infectious diseases, the ABO blood groups and human evolution. Eugen. Rev., 54, 201.

Hiraizumi, Y. (1964). Are the MN blood groups maintained by heterosis? Amer f. hum. Genet., 16, 375.

Hirschfeld, J. (1959). A simple method of determining haptoglobin groups in human sera by means of agar-gel electrophoresis. Acta path. microbiol. scand., 47, 169.

- (1960). Immuno-electrophoresis procedure and application to the study of group specific variations. Sci. Tools, 7, 18 .

- (1962). The Gc-system. Progr. Allergy, 6, 155.

(1964). Human lipoprotein polymorphism. (Proc. 1oth Congr. int. Soc. Blood Transf.). Bibl. haemat. (Basel), 23, 365

- , and Heiken, A. (1963). Application of the Gc system in paternity cases. Amer. F. hum. Genet., 15, 19.

Hodson, A. W., Latner, A. L., and Raine, L. (1962). Iso-enzymes of alkaline phosphatase. Clin. chim. Acta, 7, 255.

Hopkinson, D. A., and Harris, H. (1965). Evidence for a second 'structural' locus determining human phosphoglucomutase. Nature (Lond.), 208, 4 Io.

-, Spencer, N., and Harris, H. (1963). Red cell acid phosphatase variants: a new human polymorphism. ibid., 199, 969. 
-,$- \ldots$, and - (1964). Genetical studies on human red cell acid phosphatase. Amer. F. hum. Genet., 16, I4I.

Huehns, E. R., and Shooter, E. M. (1965). Human hasmoglobins. F. med. Genet., 2,48 .

Hughes, H. B. (1953). On the metabolic fate of isoniazid. F. Pharmacol. exp. Ther., 109, 444.

-, Biehl, J. P., Jones, A. P., and Schmidt, L. H. (1954). Metabolism of isoniazid in man as related to the occurrence of peripheral neuritis. Amer. Rev. Tuberc., 70, 266.

—-, Schmidt, L. H., and Biehl, J. P. (I955). The metabolism of isoniazid: its implications in therepeutic use. Trans. Conf. Chemother. Tuberc., 14, 217. Washington, D.C., 1955, Veterans Administration.

Jackson, C. E., Symon, W. E., and Mann, J. D. (I964). X chromosome mapping of genes for red-green color blindness and $\mathrm{Xg}$. Amer. F. hum. Genet., 16, 403.

Javid, J. (1964). The nature of the difference between haptoglobin polymers in the phenotypes $\mathrm{Hp}_{2-\mathrm{I}}$ and $\mathrm{Hp}$ 2-2. Proc.nat. Acad. Sci. (Wash.), 52, 663 .

Jenne, J. W., MacDonald, F. M., and Mendoza, E. (I96I). A study of the renal clearances, metabolic inactivation rates, and serum fall-off interaction of isoniazid and paramino-salicylic acid in man. Amer. Rev. resp. Dis., 84, 37 I.

Jeppsson, J. O., and Sjöquist, J. (1963). Separation of normal human transferrin into two fractions. Biochim. biophys. Acta (Amst.), 78, 658 .

Jonxis, J. H. P. (1965). Haemoglobinopathies in West Indian groups of African origin. In Abnormal Haemoglobins in Africa, ed. J. H. P. Jonxis, p. 329. Blackwell Scientific Publications, Oxford.

Junqueira, P. C., Kalmus, H., and Wishart, P. (1957). P.T.C. thresholds, colour vision and blood factors of Brazilian Indians. II Carajas. Ann. hum. Genet., $22,22$.

Kalmus, H. (1965). Diagnosis and Ginetics of Defective Colour Vision. Pergamon Press, Oxford.

- De Garay, A., Rodarte, U., and Cobo, L. (I964). The frequency of PTC tasting, hard ear wax, colour blindness and other genetical characters in urban and rural Mexican populations. Hum. Biol., 36, 134 .

Kaplan, A. R., Fischer, R., Glanville, E., Powell, W., Kamionkowski, M., and Fleshler, B. (1964). Differential taste sensitivities in duodenal and gastric ulcer patients. Gastroenterology, 47, 604 .

Kidson, C., and Gorman, J. G. (1962). A challenge to the concept of selection by malaria in glucose-6-phosphate dehydrogenase deficiency. Nature (Lond.), 196, 49.

Kirk, R. L. (1965). Population genetic studies of the indigenous peoples of Australia and New Guinea. Progr. med. Genet., 4, 202.

- Cleve, H., and Bearn, A. G. (1963). The distribution of the group specific component (Gc) in selected populations in South and South East Asia and Oceania. Acta genet. (Basel), 13, 140.

—, Parker, W. C., and Bearn, A. G. (1964). The distribution of the transferrin variants $D_{1}$ and $D_{c h i}$ in various populations. ibid., I4, $4 \mathrm{I}$.

Kirkman, H. N., and Hendrickson, E. M. (1963). Sex-linked electrophoretic difference in glucose-6-phosphate dehydrogenase deficiency. Amer. F. hum. Genet., 15, 241 .

Kitchin, F. D., and Bearn, A. G. (1966). The electrophoretic patterns of normal and variant phenotypes of the group specific (Gc) components in human serum. ibid., 18. $20 \mathrm{I}$.

- Howel-Evans, W., Clarke, C. A., McConnell, R. B., and Sheppard, P. M. (1959). P.T.C. taste response and thyroid disease. Brit. med. F., $\mathbf{x}, 1069$.

Knight, R. A., Selin, M. J., and Harris, H. W. (1959). Genetic factors influencing isoniazid blood levels in humans. Trans. Conf. Chemother. Tuberc., 18, 52.

Kruatrachue, M., Charoenlarp, P., Chongsuphajaisiddhi, T., and Harinasuta, C. (1962). Erythrocyte glucose-6-phosphate dehydrogenase and malaria in Thailand. Lancet, $2,1183$.

Lai, L., Nevo, S., and Steinberg, A. G. (1964). Acid phosphatases of human red cells: predicted phenotype conforms to a genetic hypothesis. Science, 145, 1187.

Lehmann, H., and Huntsman, R. G. (1966). Man's Haemoglobins. North-Holland, Amsterdam.

Levene, C., Hermoni, D., and Cividalli, L. (1965). MN heterozygotes among newborn in Israel. Israel f. med. Sci., $1,448$.
Li, C. C. (1953). Is Rh facing a crossroad; a critique of the compensation effect. Amer. Nat., 87, 257.

(1955). Population Genetics. University of Chicago Press, $\stackrel{\mathbb{1}}{-}$ Chicago.

Lie-Injo Luan Eng (1964). Haemoglobinopathies in East Asia. Ann. hum. Genet., 28, го .

Livingstone, F. B. (1960). Natural selection, disease, and ongoing $\bigcirc$ human evolution, as illustrated by the ABO blood groups. $\bar{\sigma}$ Hum. Biol., 32, 17.

(1964). Aspects of the population dynamics of the abnormal $\frac{\omega}{\vec{T}}$ haemoglobin and glucose-6-phosphate dehydrogenase deficiency genes. Amer. F. hum. Genet., 16, 435.

Luca, F. de, and Cramarossa, L. (1965). Phenylthiourea and endemic goitre. Lancet, I, 1399.

Lugg, J. W. H. (I966). Taste thresholds for phenylthiocarbamide. of some population groups. III. The thresholds of some groups living in Japan. Ann. hum. Genet., 29, 217.

Marks, P. A., and Banks, J. (I965). Drug-induced hemolytic anemias associated with glucose-6-phosphate dehydrogenase deficiency: a $\overline{3}$ genetically heterogeneous trait. Ann. N.Y. Acad. Sci., 123, 198. ق

Matsunaga, E. (1962a). The dimorphism in human normal cerumen. I Ann. hum. Genet., $25,273$.

(1962b). Selective mechanisms operating on $\mathrm{ABO}$ and $\mathrm{MN}$ blood groups with special reference to prezygotic selection. $A$ Eugen. Quart., 9, 36.

Mayr, E. (1963). Animal Species and Evolution. Harvard University Press, Cambridge, Massachusetts.

Memoria, J. M. P. (1959). Endemic goitre and sensitivity to P.T.C. $\$ Rev. bras. Malar., 11, 5 .

Menn, J. J., McBain, J. B., and Dennis, M. J. (1964). Detection of naturally occurring cholinesterase inhibitors in several crops by paper chromatography. Nature (Lond.), 202, 697.

Mitchell, R. S., Riemensnider, D. K., Harsch, J. R., and Bell, J. C. के (1958). New information on the clinical implications of individual . variations in the metabolic handling of antituberculous drugs, $\square$ particularly isoniazid. Trans. Conf. Chemother. Tuberc., 17, 77.

Montenegro, L. (1964). P.T.C. tasting among Tucano Indians Ann. hum. Genet., 28, 185.

Morton, N. E. (1965). Models and evidence in human population genetics. In Genetics Today (Proceedings of the XIth International 은 Congress of Genetics, The Hague, 1963), ed. S. J. Geerts, Vol. 3, 으 p. 935. Pergamon Press, Oxford.

, and Chung, C. S. (1959). Are the MN blood groups maintained by selection? Amer. F. hum. Genet., I1, 237

, Krieger, H., and Mi, M. P. (1966). Natural selection on polymorphisms in North Eastern Brazil. ibid., 18, 153.

Motulsky, A. G. (I964). Hereditary red cell traits and malaria. Amer. F. trop. Med. Hyg., 13, 147.

(I965). Theoretical and clinical problems of G 6 PD deficiency

In Abnormal Haemoglobins in Africa, ed. J. H. P. Jonxis, p. 143 Blackwell, Oxford.

, and Campbell-Kraut, J. M. (I962). Population genetics of 3 glucose-6-phosphate dehydrogenase deficiency of the red cell. In Proceedings of the Conference on Genetic Polymorphisms and Geographic Variation in Disease. Grune and Stratton, New York.

, Kraut, J. M., Thieme, W. T., and Musto, D. F. (1959). Biochemical genetics of glucose-6-phosphate dehydrogenase deficiency. Clin. Res., 7,89.

- , and Steinmann, L. (1962). Aryl amine acetylation in human red cells. F. clin. Invest., 41,1387 .

Nagel, R., and Soto, O. (1964). Haptoglobin types in Native Chileans: a hybrid population. Amer. F. phys. Anthrop., 22, 335. N

Neel, J. V., and Post, R. H. (1963). Transitory 'positive' selection N for colorblindness?. Eugen.Quart., 10, 33.

, Salzano, F. M., Junqueira, P. C., Keiter, F., and MayburyLewis, D. (1964). Studies on the Xavante Indians of the Brazilian Mato Grosso. Amer. F. hum. Genet., 16, 52.

Nerstrøm, B. (1963). On the inheritance of the Gc-system. A Danish family study. Acta genet. (Basel), 13, 30 .

Newcombe, H. B. (1963). Risk of fetal death to mothers of different $\mathrm{ABO}$ and $\mathrm{Rh}$ blood types. Amer. F. hum. Genet., 15, 449. (1965). Risks in ABO and Rh incompatibility. ibid., 17, 97.

Orgell, W. H. (1963). Inhibition of human plasma cholinesterase in vitro by plant extracts. Lloydia, 26, 59.

Parker, W. C., and Bearn, A. G. (1963). Control gene mutation as a possible explanation of certain haptoglobin phenotypes. Amer. f. hum. Genet., 15, 159. 
- and - (1965). Variations in heterozygous expression at the haptoglobin locus. ibid., 17, 370.

Parr, C. W., and Fitch, Linda, I. (1954). Hereditary partial deficiency of human-erythrocyte phosphogluconate dehydrogenase. Biochem. F., 93, 28c.

Penrose, L. S., Smith, S. M., and Sprott, D. A. (1956). On the stability of allelic systems, with special reference to haemoglobins A, S and C. Ann. hum. Genet., 2 I, 90.

Pickford, R. W. (1962). Compound hemizygotes for red-green colour vision defects. Vision Res., 2, 245.

Plato, C. C., Cruz, M. T., and Kurland, L. T. (1964). Frequency of glucose-6-phosphate dehydrogenase deficiency, red-green colour blindness and $\mathrm{X}_{\mathrm{g}}{ }^{\mathrm{a}}$ blood-group among Chamorros. Nature (Lond.), 202, 728.

Polonovski, M., and Jayle, M. F. (1940). Sur la préparation d'une nouvelle fraction des proteinés plasmatiques, l'haptoglobine. C. R. Acad. Sci. (Paris), $211,517$.

Porter, I. H., Boyer, S. H., Schulze, J., and McKusick, V. A. (I96I). Genetic control of glucose-6-phosphate dehydrogenase production. Proc. 2nd int. Conf. hum Genet., Rome 1961, 1, 618.

Post, R. H. (1962). Population differences in red and green color vision deficiency: A review and a query on selection relaxation. Eugen.Quart., 9, $13 \mathrm{I}$.

- - (1965). Selection against 'colorblindness' among primitive populations. ibid., 12, 28.

Powell, R. D., and Brewer, A. G. (1965). Glucose-6-phosphate dehydrogenase deficiency and falciparum malaria. Amer. $\mathcal{F}$. trop. Med. Hyg., 14, 358.

Reed, T. E. (I96I). Polymorphism and natural selection in blood groups. In Proceedings of the Conference on Genetic Polymorphisms, ed. B. S. Blumberg, p. 8o. Grune and Stratton, New York.

(1965). Magnitude of binomial variation in family data. Amer. F. hum. Genet., 17, 95.

- -, Gershowitz, H., Soni, H., and Napier, J. (1964). A search for natural selection in six blood group systems and ABH secretion. ibid., 16, 161.

Reinskou, T. (1966). Application of the Gc system in 1338 paternity cases. Vox Sang. (Basel), II, 59.

Roberts, D. F., and Boyo, A. E. (1960). On the stability of haemoglobin gene frequencies in West Africa. Ann. hum. Genet., 24, 375 .

Robson, E. B., and Harris, H. (1966). Further data on the incidence and genetics of the serum cholinesterase $\mathrm{C}_{5}+$. ibid., 29, 403 .

Rooartz, C. (1963). Données actuelles sur les groups héréditaires de gamma-globulines. Transfusion (Paris), 6, 5 .

_- Lenoir, J., and Rivat, L. (I96I). A new inheritable property of human sera: the InV factor. Nature (Lond.), 189, 586.

- , Rivat, L., and Rousseau P.-Y. (1962). Deux nouveaux facteurs dans les systèmes héréditaires de gamma-globuline: le $\mathrm{Gm}(\mathrm{e})$ et l'Inv. (Proc. 9th Congr. int. Soc. Blood Transf., Mexico.) Bibl. haemat. (Basel), 19, 455 .

,,$---\longrightarrow$, Baitsch, H., and Van Loghem, J. (1963). Les systèmes Gm et Inv en Europe. Acta genet. (Basel), 13, 109.

Saldanha, P. H. (1956). Apparent pleiotrophic effect of genes determining taste thresholds for phenylthiourea. Lancet, $2,74$.

Salzano, F. M., and Shreffler, D. C. (1966). The Gc polymorphism in the Caingang Indians of Brazil. Acta genet. (Basel), 16, 242.

, and Sutton, H. E. (1965). Haptoglobin and transferrin types of Indians from Santa Catarina, Brazil. Amer. F. hum. Genet., 17, 280.

Schelling, J.-L., Tetreault, L., Lasagna, L., and Davis, M. (1965). Abnormal taste threshold in diabetes. Lancet, $\mathbf{I}, 508$.

Sheppard, P. M. (1959). Blood groups and natural selection. Brit. med. Bull., 15, 134 .

Shim, B. S., and Bearn, A. G. (1964). The distribution of haptoglobin subtypes in various populations including subtype patterns in some nonhuman primates. Amer. F. hum. Genet., 16, 477.

Shinton, N. K., Richardson, R. W., and Williams, J. D. F. (1965). Diagnostic value of serum haptoglobin. F. clin. Path., 18, I14.

Shreffler, D. C. (1965). Genetic studies of blood group-associated variations in a human serum alkaline phosphatase. Amer. $\mathcal{F}$. hum. Genet., 17,71 .

Simpson, N. E. (1966). Factors influencing cholinesterase activity in a Brazilian population. ibid., 18, 243.

Siniscalco, M., Filippi, G., and Latte, B. (1964). Recombination between protan and deutan genes; data on their relative positions in respect of the G6PD locus. Nature (Lond.), 204, 1062.

Smithies, O. (1955). Zone electrophoresis in starch gels: group variations in the serum proteins of normal human adults. Biochem. f., 61,629 .

(1964). Starch-gel electrophoresis. Metabolism, 13, 974.

, Connell, G. E., and Dixon, G. H. (1962a). Inheritance of haptoglobin subtypes. Amer. F. hum. Genet., 14, 14.

,-- , and - (1962b). Chromosomal rearrangements and the evolution of haptoglobin genes. Nature (Lond.), 196, 232.

Spencer, N., Hopkinson, D. A., and Harris, H. (1964). Phosphoglucomutase polymorphism in man. ibid., 204, 742

Steinberg, A. G. (1962). Progress in the study of genetically determined human gamma globulin types (The Gm and Inv groups). Progr. med. Genet., 2 , I.

- , Giles, B. D., and Stauffer, R. (1960). A Gm-like factor present in Negroes and rare or absent in Whites: its relation to $\mathrm{Gm}^{\mathrm{a}}$ and $\mathrm{Gm}_{\mathrm{x}}$. Amer. F. hum. Genet., 12, 44.

- , and Goldblum, R. (1965). A genetic study of the antigens associated with the $\mathrm{Gm}(\mathrm{b})$ factor of human gamma globulin. ibid., 17, 133 .

- Wilson, J. A., and Lanset, S. (1962). A new human gamma globulin factor determined by an allele at the Inv locus. Vox Sang. (Basel), 7, $15 \mathrm{I}$.

Sunahara, S. (196I). Genetical, geographical and clinical studies on isoniazid. (Proc. I6th int. Tuberc. Conf., Toronto, Canada.) Excerpta med. (Amst.) int. Congr. ser., no. 44, 2, 513.

_- Urano, M., and Ogawa, M. (I96I). Genetical and geographic studies on isoniazid inactivation. Science, 134,1530 .

Sutton, H. E., and Karp., G. W. (1964). Variations in the heterozygous expression at the haptoglobin locus. Amer. F. hum. Genet., 16, 419.

Tarlov, A. R., Brewer, G. J., Carson, P. E., and Alving, A. S. (I962). Primaquine sensitivity: Glucose-6-phosphate dehydrogenase deficiency: an inborn error of metabolism of medical and biological significance. Arch. intern. Med., 109, 209.

Terry, M. C., and Segall, G. (1947). The association of diabetes and taste-blindness. f. Hered., 38, 135; Postscript (by Terry) ibid., 38, 378.

Thomas, K., and Kampf, D. (196I). Die verebbaren Gm-Serumeiweissgruppen: ein neuer Faktor, Gm Dresden, in diesem System. Dtsch. Gesundh.-Wes., 16, 1185.

Thompson, G. R. (1962). Significance of haemoglobins $S$ and $C$ in Ghana. Brit. med. F., 1, 682 .

Thuline, H. (1964). Color-vision defects in American school children. F. Amer. med. Ass., 188, 514.

Trujillo, J., Fairbanks, V., Ohno, S., and Beutler, E. (196I). Chromosomal constitituion in glucose-6-phosphate dehydrogenase deficiency. Lancet, 2, 1454.

VanderDonck, R., and Verriest, G. (1960). Femme protanomale et hétérozygote mixte (Gènes de la protanomalie et de la deutéranopie en position de répulsion), ayant deux fils deutéranopes, un fils protanomal et deux fils normaux. Biotypologie, 21 , 1 IO.

Vogel, F., Pettenkofer, H. J., and Helmbold, W. (1960). Uber die Populationsgenetik der ABO Blutgruppen. 2. Mitteilung. Genhäufigkeit und epidemische Erkrankungen. Acta genet. (Basel), 10, 267.

Wang, A.-C., and Sutton, H. E. (1965). Human transferrins C and $\mathrm{D}_{1}$ : chemical differences in a peptide. Science, $149,435$.

Weatherall, D. J. (1965). The Thalassaemia Syndromes. Blackwell Oxford.

Weiser, M. M., Bolt, R. J., and Pollard, H. M. (1964). Isozyme patterns of the human gastrointestinal tract in the normal state and in nontropical sprue. F. Lab. clin. Med., 63, 656 .

Went, L. N. (I96I). Segregation-ratio advantage of abnormal haemoglobins. Nature (Lond.), 192, 382.

Wiener, A. S. (1965). Blood groups and personality traits. Amer. F. hum. Genet., 17, 369.

, Gordon, E. B., and Wexler, J. P. (1963). The M-N types, with special reference to the mating $M N \times M N$. Exp. Med. Surg., $21,89$.

Witzleben, C. L., and Wyatt, J. P. (1961). The effect of long survival on the pathology of thalassaemia major. F. Path. Bact., $82, \mathrm{I}$.

Zinkham, W. H., and Lenhard, R. E., Jr. (1959). Metabolic abnormalities of erythrocytes from patients with congenital nonspherocytic haemolytic anemia. f. Pediat., 55, 319. 